\title{
INCOME-BASED DISPARITIES IN EARLY ELEMENTARY SCHOOL SCIENCE ACHIEVEMENT
}

\begin{abstract}
A B S T RACT
This study documents gaps in kindergarten and firstgrade science achievement by family income and explores the degree to which such gaps can be accounted for by student race/ethnicity, out-of-school activities, parental education, and school fixed effects. In doing so, it expands on prior research that documents disparate rates of science achievement by income in upper elementary and high school. The study uses nationally representative data from the Early Childhood Longitudinal Study of 2011. Findings suggest a science achievement gap of approximately 1 standard deviation between students from families near the goth percentile of income and those from families near the 1oth percentile of income. Race/ethnicity, out-of-school activities, parental education, and school fixed effects explain approximately one third of this gap each. The results suggest the need to focus on both in-school and out-of-school factors as part of a concerted effort to improve equity in science education.
\end{abstract}

\section{F. Chris Curran}

UNIVERSITY OF

MARYLAND, BALTIMORE

COUNTY

THE ELEMENTARY SCHOOL JOURNAL

Volume 118, Number 2. Published online October 30, 2017

(C) 2017 by The University of Chicago. All rights reserved. 0013-5984/2017/11802-0002\$10.00 
Smith, \& Strohl, 2013; Langdon, McKittrick, Beede, Khan, \& Doms, 2011). Even for students who do not pursue careers in science, an enhanced understanding of scientific content is becoming increasingly important for engaging in civic discourse as policy issues such as global warming and pharmaceutical practices remain central issues of the day (Lee \& Buxton, 2010; Quinn, Schweingruber, \& Keller, 2012; "Top 10 Legislative Issues," 2015). Consequently, preparing students with the skills necessary to acquire and excel at jobs in science fields and to engage in policy discourse is important both for their personal outcomes and for the competitiveness of the nation as a whole.

Despite the importance of science knowledge for individual and societal economic and civic progress, not all groups of students are positioned to equally partake and benefit from this progress. In particular, students from the lowest economic backgrounds disproportionately underperform on national and international assessments of science achievement (Gonzales et al., 2008; Kohlhaas, Lin, \& Chu, 2010a; National Center for Education Statistics, 2012a). Such disparities are borne out as students progress to postsecondary schooling and to the workforce, resulting in obstacles for students from lower income backgrounds to leverage the increased availability of science-related jobs as a mechanism for social mobility and a decreased ability to fully engage in informed civic debate regarding scientific issues (Bacharach, Baumeister, \& Furr, 2003; Bailey \& Dynarski, 2011; Chen \& Weko, 2009).

Despite the available evidence on income-based science achievement gaps at the upper elementary, middle, and high school levels (Kohlhaas, Lin, \& Chu, 2010b; Lee \& Buxton, 2008; National Center for Education Statistics, 2012a, 2012b; Quinn \& Cooc, 2015), comparatively few studies have systematically examined incomebased science achievement gaps in the earliest grades and the factors that explain these gaps. Studying early science achievement gaps is important, given evidence demonstrating that income-based mathematics and reading achievement gaps are present at the start of schooling, can expand as students move through the first few years of formal schooling, and are explainable by both in-school and out-of-school factors (ACT, 2012; Bodovski \& Farkas, 2007; Jordan, Kaplan, Nabors Oláh, \& Locuniak, 2006; Reardon, 2011; Robinson, 2013).

The purpose of this study is to explore disparities in early science achievement across family income levels. Understanding the size of income-based science achievement gaps at the start of school as well as the factors that explain such gaps has the potential to inform policy and interventions designed to increase science achievement of students from lower income backgrounds. This study addresses the following research questions: $(a)$ What is the relationship between family income and science achievement in kindergarten and first grade? (b) To what extent are income-based science achievement gaps in kindergarten explained by student race/ethnicity, by differential out-of-school activities engaged in by students, by differential education levels of parents, or by variations across schools? (c) How do income-based achievement gaps in science compare with those in mathematics and reading?

Answering these research questions builds on prior work on income-based achievement gaps (e.g., Reardon, 2011) by expanding examination to science achievement, a previously understudied outcome. To the extent that science achievement in 
the early grades represents an important first step toward later engagement and success with science majors and science careers, understanding these gaps has the potential to inform policy that can create more equitable outcomes in science.

\section{Background}

The existence of systematic differences in achievement, or achievement gaps, across groups has been a well-documented phenomenon for many years. In general, early research and policy initiatives focused on racial achievement gaps, particularly the Black-White gap. For instance, the Coleman Report, conducted in the 1960s, documented systematic differences in achievement between Black and White students (Coleman et al., 1966), and the continued existence of racial gaps has been well documented by numerous researchers (Fryer \& Levitt, 2004; Jencks \& Phillips, 2011; Magnuson \& Waldfogel, 2008; Oakes, 1990). Recently, however, studies have focused on the achievement gap between students from low- and high-income households, noting that this income-based achievement gap has grown significantly over the past several decades and is now considerably larger than the corresponding Black-White gap (Duncan \& Murnane, 2011; Reardon, 2011).

The documentation and attention to the income achievement gap has paralleled increases in economic disparities in the United States. For instance, over the past several decades, the gap between the wealthiest and the poorest Americans has increased significantly, reaching levels as large as any seen in the last century (Burkhauser, Feng, Jenkins, \& Larrimore, 2012; Piketty \& Saez, 2003). Although the exact cause of the increasing income-based achievement gap remains a point of some discussion, possible explanations include greater disparities in wealth as well as increased education levels of wealthier parents and more concerted efforts by wealthier parents to cultivate their children's education (Reardon, 2011). To date, the work on income-based achievement gaps has tended to focus on the academic outcomes of mathematics and reading (Duncan \& Magnuson, 2011; Reardon, 2011). For instance, Reardon (2011) found that students from families at the ninetieth percentile of income score approximately 1.25 standard deviations $(S D)$ higher than students at the tenth percentile of income in both mathematics and reading. Although evidence documents disparities in participation in science at the higher levels of secondary school, postsecondary education, and the workforce, it is likely that the foundation of such disparities begins early in students' academic trajectories (Lee \& Buxton, 2008; Muller, Stage, \& Kinzie, 2001; Nussbaum, Hamilton, \& Snow, 1997; Oakes, 1990).

Despite the potential importance of early elementary precursors to later disparities in science achievement, prior evidence on science achievement gaps in the earliest grades of elementary school is limited. Some of the best evidence on income-based disparities in science comes from results of the National Assessment of Educational Progress (NAEP), a nationally representative assessment. Results from the NAEP suggest that achievement gaps in science exist across family income (National Center for Education Statistics, 2012a). For instance, in 2011, eighth-grade students who were eligible for the National School Lunch Program (NSLP) scored approximately 0.75 SD lower than students who were not eligible 
for NSLP, a gap similar to that observed in 2009 (National Center for Education Statistics, 2012a; U.S. Department of Education, 2012). A similarly sized gap was also found between fourth-grade students who were eligible for free lunch and those who were not in 2009 (National Center for Education Statistics, 2011; U.S. Department of Education, 2012). Results on subportions of the NAEP examination further demonstrate this income-based achievement gap. For instance, fourth- and eighth-grade students eligible for the NSLP scored systematically lower than those not eligible on assessments of hands-on science tasks and interactive computer tasks (National Center for Education Statistics, 2012b).

Measures of income-based science achievement gaps from the NAEP, however, are limited. In particular, the NAEP uses eligibility for the NSLP as a proxy for family income. This indicator of income potentially masks important variation in science achievement across the income gradient. Furthermore, given that some schools provide free meals to all students, regardless of individual eligibility, the NAEP data may include a number of students eligible for the NSLP despite having higher family income, thereby potentially attenuating estimates of the incomebased science achievement gap. Finally, the NAEP data do not assess students in science below fourth grade, preventing an assessment of the early emergence of such gaps.

This final limitation of the NAEP science data is a particularly important shortcoming because a number of studies demonstrate mathematics and reading achievement gaps between students from low- and high-income households at the start of kindergarten (Jordan et al., 2006; Reardon, 2011; Robinson, 2013). Furthermore, some evidence suggests that achievement gaps can change over time as cohorts of students progress through school. For instance, Fryer and Levitt (2004) demonstrate that the reading and mathematics achievement gaps by race expand during the first few years of formal schooling. Similarly, evidence from the Explore, PLAN, and ACT assessments demonstrate a widening of racial achievement gaps in science as students progress through secondary schooling (ACT, 2012). Compared with racial gaps, however, evidence regarding changes in income gaps as students progress through school suggests they may display a more stable pattern (Duncan \& Magnuson, 2011; Reardon, 2011).

Despite the increased policy attention to science achievement, few studies have systematically examined income-based science achievement gaps. Analysis using NAEP data does not examine grades below fourth grade and uses only a rough proxy, NSLP eligibility, for family income (National Center for Education Statistics, 2011, 2012a, 2012b). Other work using nationally representative data sets has also been limited by a lack of science tests in the earliest grades. For instance, Kohlhaas and colleagues (2010b) document income disparities in science achievement in third grade using data from the original Early Childhood Longitudinal Study (ECLS-K); however, the data set does not include science examinations in the earliest grades. More recently, researchers have estimated the gap between the highest and lowest quintile of socioeconomic status (a composite of income, education levels, and job prestige) at approximately $1 S D$ in third through eighth grades (Morgan, Farkas, Hillemeier, \& Maczuga, 2016). In addition, socioeconomic gaps at kindergarten in general knowledge achievement - a measure including sci- 
ence and social studies concepts - have been documented (Morgan et al., 2016). Although providing suggestive evidence of early income-based disparities in science achievement, these prior studies have been limited by a lack of true science achievement measures in the earliest grades.

Given evidence that achievement gaps in other subjects present early in students' academic trajectories (Jordan et al., 2006; Reardon, 2011; Robinson, 2013) and that such gaps can change over the first few years of schooling (Fryer \& Levitt, 2004), there is a need to better understand income-based science achievement gaps in the earliest grades. Furthermore, given that assessments from studies such as the NAEP focus on aggregated scores, such assessments do not allow for detailed exploration of the factors contributing to income-based science achievement gaps, thereby providing limited information regarding the most promising ways to address these gaps.

This study fills these voids in the literature by examining income-based science achievement gaps in kindergarten and first grade, using data that include more detailed measures of family income and that allow for exploration of the degree to which factors such as race/ethnicity, out-of-school activities, parental education, and across-school variation explain the income-based science achievement gap. In doing so, this study provides some of the first evidence on income-based science achievement gaps in the earliest grades of formal schooling and better elucidates the mechanisms that may contribute to such gaps.

\section{Theoretical Framework}

Ecological systems theory and the conceptual framework of opportunity to learn provide mechanisms for understanding systematic gaps in academic achievement between subgroups of students. The ecological systems theory posits that students are influenced by their context, including the experiences in their schools, homes, neighborhoods, and broader communities (Bronfenbrenner, 1992; Bronfenbrenner \& Morris, 2006). Empirical research demonstrates that the contexts experienced by students from lower income families differ systematically from those experienced by their peers from higher income families. In particular, students from lower income families are less likely to be exposed to a rich vocabulary, have less access to high-quality early learning experiences, and generally have parents who are themselves less educated and who possess fewer resources to promote early learning (Hart \& Risley, 1995; Kaushal, Magnuson, \& Waldfogel, 2011; Meyers, Rosenbaum, Ruhm, \& Waldfogel, 2004; Reardon, 2011).

These differences represent gaps in opportunity to learn between students from higher and lower income households. The concept of opportunity to learn suggests that student learning can occur only when students are given exposure and opportunity to engage with the content to be learned (Carroll, 1963, 1989). Indeed, in formal education settings, the empirical literature suggests that increased time on content and exposure to more advanced academic content predicts greater student learning (Claessens, Engel, \& Curran, 2014; Gamoran, Porter, Smithson, \& White, 1997; Jez \& Wassmer, 2015; Wang, 1998). To the extent that the context experienced 
by lower income students prior to kindergarten includes fewer opportunities to learn science, we would expect an income-based early achievement gap to exist at the start of formal schooling. Taken together, ecological systems theory and the opportunity to learn framework provide theoretical grounding for differences in achievement between students from higher and lower income households.

Indeed, such gaps have been well documented in mathematics and reading (i.e., Duncan \& Murnane, 2011; Reardon, 2011). Although similar gaps may be expected in science, there are theoretical reasons why early gaps in science may differ from those in reading and mathematics. First, students from lower income households may experience fewer opportunities to supplement their knowledge of science compared with reading and mathematics because of the lack of priority given to early science. Although reading and mathematics are pushed as priorities in the preschool and early elementary grades, science has generally been viewed as a less important subject. Indeed, research shows that far less time is spent on science instruction in elementary school than on reading and mathematics (Bassok, Latham, \& Rorem, 2016; Bowdon \& Desimone, 2014). To the extent that science is not prioritized by parents or by early educational settings, there may be fewer opportunities to reduce learning gaps in science compared with reading and mathematics, which would, in turn, result in larger science achievement gaps.

In addition, early science gaps may be larger than those in reading or mathematics as a result of the foundational nature of reading and mathematics for science performance (Morgan et al., 2016). In particular, students who struggle with reading may have fewer opportunities to engage with science content (Connor et al., 2012). Similarly, students who lack foundational mathematics skills may struggle to comprehend graphs and other mathematical representations of science. Consequently, gaps in reading and mathematics may serve to further reinforce gaps in scientific achievement.

Although the mechanisms of differences in science achievement gaps and those in reading and mathematics have not been the focus of many studies, recent empirical evidence demonstrates that the size of science gaps can be significantly different than those in reading and mathematics. For instance, Curran and Kellogg (2016) find that Asian and White students perform about the same, on average, in reading and mathematics in kindergarten but that Asian students perform nearly 0.5 SD lower than White students in science. Similarly, they find that the reading and mathematics gaps for Hispanic and Black students are consistently smaller than the science gap (Curran \& Kellogg, 2016). Taken as a whole, theory and empirical work suggest the likelihood of early income-based science achievement gaps while also suggesting the possibility that such gaps may not directly mirror those in reading and mathematics.

\section{Data}

I draw on data from the most recent iteration of the ECLS-K, which consists of a nationally representative set of students who began kindergarten in the 2010-11 school year (ECLS-K:2011; Tourangeau et al., 2015). The study will eventually follow these students through fifth grade. The ECLS-K:2011 provides the most up-to- 
date data on the experiences of students in elementary school, updating data collected in the original ECLS-K which began in 1998-99 (Tourangeau et al., 2015; Tourangeau, Nord, Lê, Sorongon, \& Najarian, 2009).

A unique feature of the ECLS-K:2011 is the inclusion of science achievement tests in the earliest grades. The prior iteration of the ECLS-K did not include science achievement tests until students were in third grade, preventing examination of science achievement in the earliest years of formal schooling (Tourangeau et al., 2009). The ECLS-K:2011 science assessment included questions pertaining to the physical sciences, life sciences, environmental sciences, and scientific inquiry (Tourangeau et al., 2015). In the kindergarten year, the science assessment included a consistent set of 20 items for all students, whereas in the first-grade year the assessment used a two-stage approach in which routing questions ensured that the questions could precisely measure each child's skills (Tourangeau et al., 2015). In both years, the science assessments were administered verbally using an easel to present the question, any graphs or figures, and the response options while having the test administrator read aloud the question and answers (Tourangeau et al., 2015).

The science achievement tests used in the ECLS-K:2011 were developed through an iterative process to ensure their validity and reliability. In particular, the kindergarten science tests were based on commonalities in the 2009 science standards from six states (Arizona, California, Florida, New Mexico, Texas, and Virginia) and then further revised by a panel of educators and subject area curriculum specialists (Tourangeau et al., 2015). Field tests were conducted on the assessments prior to selection of the final assessment items (Tourangeau et al., 2015). As such, the science assessments have a high level of validity, reflecting kindergarten science standards across multiple states and the expertise of subject matter experts. The science theta scores had reliability of 0.75 , lower than reliability for mathematics and reading as a result of the wider range of content assessed on the science achievement test (Tourangeau et al., 2015).

I used standardized versions of the science theta score that were derived from item response theory measures. In particular, measures were standardized $(M=0$, $S D=1$ ) within each year using sampling weights and survey settings to account for the complex sampling design of the ECLS-K:2011. Results from alternative approaches to standardization, including standardization without accounting for weighting or the sampling design, produced qualitatively similar results.

It is important to note that standardized science achievement tests represent but one metric of science learning and ability. Research has established the importance of attitudes toward schooling and nonacademic outcomes as well as other metrics of academic achievement and measures of inequities in education (Moore, Lippman, \& Ryberg, 2015; Wilder, Jacobsen, \& Rothstein, 2008). Nevertheless, achievement gaps on standardized achievement tests remain a primary driver in education policy debates and are readily measurable with the given data. Consequently, I used the standardized science achievement measures while recognizing that they do not capture all important science-related student outcomes.

In addition to science achievement scores, the ECLS-K:2011 includes a rich set of parental, teacher, and school measures. The primary independent variable of interest in this study was parental reported income. The ECLS-K:2011 reports income in 18 categories, ranging from $\$ 0$ to $\$ 5,000$ per year up to $\$ 200,001$ or more per year. For 
the range of $\$ 0$ to $\$ 75,000$, these categories cover $\$ 5,000$ increments, allowing for fairly precise estimates of family income in this range. Table 1 provides descriptive statistics on the income indicators and the kindergarten science achievement score.

In addition to the primary independent and dependent variables, I also explored, in some models, the degree to which other covariates explained the income-based science achievement gap. Given evidence of the relationship between race/ethnicity and science achievement (Curran \& Kellogg, 2016; Morgan et al., 2016), I used binary indicators of student race as explanatory variables. I also sought to understand the role of out-of-school activities through a series of indicators for the frequency with which children took part in particular activities, such as being read to, practicing numbers, going to the library, and so forth. Given evidence of the importance of formal early childhood education for subsequent achievement (Fitzpatrick, 2008; Gormley, Phillips, \& Gayer, 2008; Magnuson, Ruhm, \& Waldfogel, 2007), I also used indicators of participation in center-based childcare, Head Start, parental care, or nonparental care. Finally, given the increasing relationship between income and parental education (Reardon, 2011), I included measures of the highest level of education attained by the primary parent respondent. The full list of these measures, along with descriptive statistics, can be found in Table 2. The final weighted analytic sample consisted of 10,066 students, who had science achievement scores in kindergarten, and measures of student race/ethnicity, out-of-school activities, parental education, and school identifiers.

\section{Method}

For the purposes of this study, I used data from the kindergarten and first-grade rounds of the ECLS-K:2011. In particular, I focused on the standardized science achievement outcome as the dependent variable of interest and parental reported

Table 1. Means of Independent and Dependent Variables

\begin{tabular}{lc}
\hline Family Income (\$) & $M$ \\
\hline Less than 5,001 & .030 \\
5,001-10,000 & .035 \\
10,001-15,000 & .056 \\
15,001-20,000 & .057 \\
20,001-25,000 & .077 \\
25,001-30,000 & .048 \\
30,001-35,000 & .047 \\
35,001-40,000 & .047 \\
$40,001-45,000$ & .033 \\
45,001-50,000 & .037 \\
$50,001-55,000$ & .034 \\
55,001-60,000 & .032 \\
60,001-65,000 & .034 \\
$65,001-70,000$ & .034 \\
70,001-75,000 & .041 \\
75,001-100,000 & .139 \\
100,001-200,000 & .172 \\
200,001 or more & .045 \\
Spring kindergarten science achievement (standardized) & .020 \\
\hline \multicolumn{1}{c}{ Note- -All means weighted to account for sampling design of ECLS-K:2011. } \\
\end{tabular}


Table 2. Means of Explanatory Variables

\begin{tabular}{|c|c|c|c|}
\hline Variable & $M$ & Variable & $M$ \\
\hline Tell stories to child: & & Look at picture books: & \\
\hline Not at all & .023 & Not at all & .018 \\
\hline Once or twice a week & .258 & Once or twice a week & .157 \\
\hline 3-6 times a week & .312 & 3-6 times a week & .303 \\
\hline Every day & .408 & Every day & .522 \\
\hline Sing songs with child: & & In the past month: & \\
\hline Not at all & .034 & Visited a library & .604 \\
\hline Once or twice a week & .228 & Visited a bookstore & .573 \\
\hline 3-6 times a week & .290 & Went to play, concert, or live show & .414 \\
\hline Every day & .448 & Visited art gallery, museum, or historical site & .353 \\
\hline Help child do arts and crafts: & & Visited a zoo, aquarium, or petting farm & .456 \\
\hline Not at all & .035 & Ever participated in: & \\
\hline Once or twice a week & .368 & Clubs or recreational programs & .132 \\
\hline 3-6 times a week & .375 & Music lessons & .098 \\
\hline Every day & .222 & Drama classes & .023 \\
\hline Play games or do puzzles with child: & & Art classes or lessons & .089 \\
\hline Not at all & .021 & Performing arts & .160 \\
\hline Once or twice a week & .313 & Non-English language instruction & .068 \\
\hline 3-6 times a week & .430 & Child uses home computer & .753 \\
\hline Every day & .235 & Minutes spent reading & 20.310 \\
\hline $\begin{array}{l}\text { Talk about nature or do science projects } \\
\text { with child: }\end{array}$ & & $\begin{array}{l}\text { Number of children books in house } \\
\text { Early childhood care: }\end{array}$ & 91.420 \\
\hline Not at all & .148 & Parental care & .199 \\
\hline Once or twice a week & .501 & Nonparental care & .172 \\
\hline 3-6 times a week & .233 & Center-based care & .455 \\
\hline Every day & .118 & Head Start & .153 \\
\hline Build or play with construction toys: & & Primary respondent parental education: & \\
\hline Not at all & .126 & 8th grade or below & .038 \\
\hline Once or twice a week & .431 & 9th-12th grade & .070 \\
\hline 3-6 times a week & .277 & High school diploma or equivalent & .198 \\
\hline Every day & .167 & Vocational/technical program & .056 \\
\hline Practice reading, writing, or working with & & Some college & .273 \\
\hline numbers: & & Bachelor's degree & .222 \\
\hline Not at all & .004 & Graduate/professional school-no degree & .020 \\
\hline Once or twice a week & .066 & Master's degree or higher & .122 \\
\hline 3-6 times a week & .314 & Child race/ethnicity: & \\
\hline Every day & .617 & White & .581 \\
\hline Read books to child: & & Black & .120 \\
\hline Not at all & .000 & Hispanic & .211 \\
\hline Once or twice a week & .121 & Asian & .035 \\
\hline 3-6 times a week & .338 & Other & .053 \\
\hline Every day & .541 & & \\
\hline
\end{tabular}

Note.-All means weighted to account for sampling design of ECLS-K:2011.

income as the key independent variable of interest. In addition, in some models, I used various combinations of student race/ethnicity indicators, a series of out-ofschool activities variables, parental education measures, and school fixed effects as additional explanatory variables of interest. My analytic sample was restricted to observations that included science achievement scores for the spring of kindergarten as well as parental income measures in the kindergarten year. Adjusted for nonresponse to parental surveys, the full weighted sample contained 10,922 observations. Applying case-wise deletion of observations missing the science test score and other covariates resulted in a loss of approximately $7 \%$ of the sample. Consequently, the final weighted analytic sample consisted of 10,066 students. 
The interest of this study was in modeling the relationship between family income and science achievement in the earliest grades. The primary model was as follows:

$$
\text { ScienceAchievement }_{i}=\beta_{\circ}+\beta_{1} \text { Income }_{i}+e_{i},
$$

where ScienceAchievement represents the standardized science test score for student $i$, and Income represents a vector of dummy variables (o/1) representing the series of income categories present in the ECLS-K:2011 for the student at the kindergarten year. In this model, the coefficients on each of the income dummy variables can be interpreted as the standardized income-based science achievement gap between students in that income bracket and students in the omitted income category ( $\$ 0-$ $\$ 5,000)$. Similarly, comparisons of coefficients from particular income brackets can be compared to estimate the income-based science achievement gap between any given pair of income brackets.

In addition to the primary model, I also explored the degree to which student race/ethnicity, differential out-of-school activities, differential parental education, and variation across schools could account for the income-based science achievement gaps. I estimated four additional versions of equation (1). The first included binary indicators of a student's race/ethnicity. The second included a series of indicators for out-of-school activities, such as parents reading to the child and the child's participation in early childhood education. The third of these additional models included measures of parental education. Finally, the fourth version included school fixed effects to account for any across-school variation, thereby restricting estimates of the income achievement gaps to variation within schools. School fixed-effects models implicitly control for all characteristics shared in common among students within the school. For instance, such models would implicitly control for characteristics of the principal, structural characteristics of the school, region of the country, and so forth. In other words, these models estimated the achievement gaps between students within the same school. All models included appropriate weights to account for the complex sampling design of the ECLS-K:2011 as well as Taylor series linearization adjustments of standard errors to account for clustering of students.

\section{Results}

Analysis revealed that income-based science achievement gaps are present in the earliest years of formal schooling and that the size of these gaps is substantial. Furthermore, student race/ethnicity, out-of-school activities, parental education, and school fixed effects explained approximately one third of the gap each, although models including all four still left a portion of the gap unexplained. In addition, results indicated that the income-based achievement gaps in science are generally equal to or slightly larger than the corresponding gaps in mathematics or reading. In this section, I present the results from the models supporting each of these findings.

\section{Magnitude of the Income-Based Science Achievement Gap}

I find that the income-based science achievement gap is substantial in kindergarten. Figure 1 displays coefficients from models predicting standardized science achievement from a series of indicators for family income. Compared with the 


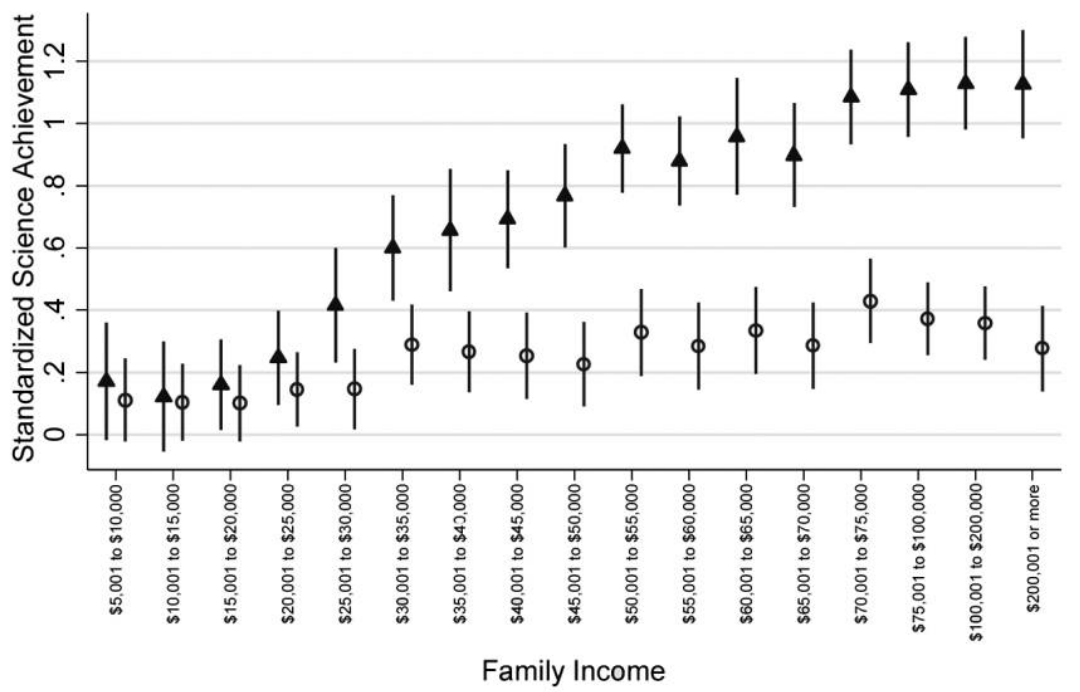

- Raw Gap ○ All Adjustments

Figure 1. Income-based science achievement gap in spring of kindergarten without controls and with race/ethnicity, out-of-school activities, parental education, and school fixed effect adjustments. Bars show 95\% confidence intervals. All estimates weighted and adjusted for ECLS-K:2011's complex sampling design.

omitted category of families with an income of less than \$5,001, a statistically significant difference in achievement scores becomes apparent for students from families with incomes of at least $\$ 15,000$.

Although the size of the gap consistently grows as income level increases, a useful comparison established in the literature is between students from families at the ninetieth percentile of income and those at the tenth percentile (Reardon, 2011). Although the categorical nature of the income data precludes a perfect measure of the ninetieth and tenth percentile, I approximated this gap by comparing students with family income in the $\$ 10,001$ to $\$ 15,000$ range (ranges from approximately the seventh to thirteenth percentile in the data) and those in the $\$ 100,001$ to $\$ 200,000$ range (ranges from approximately the seventy-ninth to the ninety-sixth percentile in the data; DeNavas-Walt \& Proctor, 2015). On average, students from families at approximately the ninetieth percentile of income scored about 1.01 SD higher in science achievement than did students at approximately the tenth percentile. On the ECLS-K:2011 science assessment, this difference is equivalent to the gains made by students between the kindergarten and first-grade assessments. In other words, students near the ninetieth percentile scored roughly one grade level higher than students near the tenth percentile. Interestingly, the gap between those near the tenth percentile and those at the median $(\$ 50,001-\$ 55,000$ range) was significantly larger (approximately $0.80 \mathrm{SD}$ ) than the gap between those at the median and near the ninetieth percentile ( $0.21 S D$ ). This finding indicates a strong nonlinearity in the income-based science achievement gap. In particular, the gap between those near the median of income and those near the tenth percentile is more than 3 times larger than that for students near the ninetieth percentile and those near the median. 


\section{Factors that Explain the Income-Based Science Achievement Gap}

Turning to explanatory factors of the income-based science achievement gap, I found that controlling for student race/ethnicity, out-of-school activities, parental education, and school fixed effects each accounted for approximately one third of the income gap between students with family incomes near the ninetieth percentile and those with incomes near the tenth percentile. Table 3 provides results from regressions predicting standardized science achievement in the spring of kindergarten from parental income with various sets of controls. As shown, the effects of controlling for student race/ethnicity (column 2), out-of-school activities (column 3), primary parent education (column 4), and school fixed effects (column 5) were similar. Even in models controlling for all four sets of covariates (column 6), a statistically significant income-based achievement gap existed, although the magnitude of the ninetieth to tenth percentile comparison was reduced to less than one third of that in the base model. The fully controlled model can be interpreted as the income-based gap that remains when comparing students of the same race/ethnicity, in the same school, with parents of similar education level, and who engage in similar out-of-school activities. In other words, even after accounting for these differences in students, there was still a significant difference in science achievement between students from lower and higher income families. Figure 1 compares the coefficients for the base model and the fully controlled model, visually demonstrating the degree to which the explanatory variables account for the raw achievement gaps.

Although the purpose of this study was not to estimate the causal effect of any given covariate on science achievement, it can nevertheless be useful to consider some of the covariates that are predictive of science achievement. Table A1 presents regression coefficients from all covariates included in the models and reveals a few interesting results. First, models including race/ethnicity demonstrate significant racial achievement gaps in science, even after controlling for income. In particular, Black, Hispanic, and Asian students perform lower on average than their White peers in science.

Although predictors of race/ethnicity and other explanatory factors such as parental education may not be particularly malleable, the out-of-school activities engaged in by students represent a potentially modifiable area for intervention. Examination of these coefficients yielded several significant relationships. Covariates related to reading and literacy (reading books to the child, number of books in the household, visiting a library, and time spent reading) were significant predictors of higher science achievement. In addition, covariates related to exploration of the natural world or scientific concepts were also significant predictors of higher science achievement. For instance, in the fully specified model, each of the following variables predicted higher science achievement: visiting an art gallery, museum, or historical site; talking about nature or doing a science project; and playing games or doing puzzles. Finally, participation in center-based preschool was also predictive of higher science achievement. Although these relationships should not be interpreted causally, these exploratory findings suggest possible mechanisms for improving science achievement and reducing income-based achievement gaps. 
Table 3. Results from Regressions Predicting Standardized Science Achievement in Spring of Kindergarten from Family Income Categories

\begin{tabular}{|c|c|c|c|c|c|c|}
\hline & (1) & (2) & (3) & (4) & (5) & (6) \\
\hline$\$ 5,001-\$ 10,000$ & $\begin{array}{c}.170 \\
(.0955)\end{array}$ & $\begin{array}{l}.133 \\
(.0823)\end{array}$ & $\begin{array}{l}.156 \\
(.0895)\end{array}$ & $\begin{array}{l}.168 \\
(.0923)\end{array}$ & $\begin{array}{l}.130 \\
(.0717)\end{array}$ & $\begin{array}{l}.111 \\
(.0683)\end{array}$ \\
\hline$\$ 10,001-\$ 15,000$ & $\begin{array}{l}.121 \\
(.0894)\end{array}$ & $\begin{array}{l}.113 \\
(.0856)\end{array}$ & $\begin{array}{l}.0848 \\
(.0866)\end{array}$ & $\begin{array}{l}.132 \\
(.0902)\end{array}$ & $\begin{array}{l}.153^{*} \\
(.0662)\end{array}$ & $\begin{array}{l}.104 \\
(.0632)\end{array}$ \\
\hline$\$ 15,001-\$ 20,000$ & $\begin{array}{l}.160^{*} \\
(.0733)\end{array}$ & $\begin{array}{l}.112 \\
(.0722)\end{array}$ & $\begin{array}{l}.135 \\
(.0746)\end{array}$ & $\begin{array}{l}.120 \\
(.0726)\end{array}$ & $\begin{array}{l}.148^{*} \\
(.0655)\end{array}$ & $\begin{array}{l}.101 \\
(.0625)\end{array}$ \\
\hline$\$ 20,001-\$ 25,000$ & $\begin{array}{l}.246^{* *} \\
(.0770)\end{array}$ & $\begin{array}{l}.195^{* *} \\
(.0662)\end{array}$ & $\begin{array}{l}.149^{*} \\
(.0752)\end{array}$ & $\begin{array}{c}.185^{*} \\
(.0775)\end{array}$ & $\begin{array}{l}.241^{* *} \\
(.0635)\end{array}$ & $\begin{array}{l}.144^{*} \\
(.0607)\end{array}$ \\
\hline$\$ 25,001-\$ 30,000$ & $\begin{array}{l}.416^{* *} \\
(.0936)\end{array}$ & $\begin{array}{l}.338^{* *} \\
(.0811)\end{array}$ & $\begin{array}{l}.261^{* *} \\
(.0911)\end{array}$ & $\begin{array}{l}.267^{* *} \\
(.0844)\end{array}$ & $\begin{array}{l}.277^{* *} \\
(.0682)\end{array}$ & $\begin{array}{l}.146^{*} \\
(.0655)\end{array}$ \\
\hline$\$ 30,001-\$ 35,000$ & $\begin{array}{l}.600^{* *} \\
(.0859)\end{array}$ & $\begin{array}{l}.451^{* *} \\
(.0749)\end{array}$ & $\begin{array}{l}.429^{* *} \\
(.0814)\end{array}$ & $\begin{array}{l}.414^{* *} \\
(.0858)\end{array}$ & $\begin{array}{l}.449^{* *} \\
(.0685)\end{array}$ & $\begin{array}{l}.288^{* *} \\
(.0658)\end{array}$ \\
\hline$\$ 35,001-\$ 40,000$ & $\begin{array}{l}.657^{* *} \\
(.0995)\end{array}$ & $\begin{array}{l}.485^{* *} \\
(.0874)\end{array}$ & $\begin{array}{l}.422^{* *} \\
(.0937)\end{array}$ & $\begin{array}{l}.425^{* *} \\
(.0984)\end{array}$ & $\begin{array}{l}.493^{* *} \\
(.0685)\end{array}$ & $\begin{array}{l}.267^{* *} \\
(.0660)\end{array}$ \\
\hline$\$ 40,001-\$ 45,000$ & $\begin{array}{l}.693^{* *} \\
(.0796)\end{array}$ & $\begin{array}{l}.491^{* *} \\
(.0682)\end{array}$ & $\begin{array}{l}.457^{* *} \\
(.0720)\end{array}$ & $\begin{array}{l}.469^{* *} \\
(.0783)\end{array}$ & $\begin{array}{l}.470^{* *} \\
(.0735)\end{array}$ & $\begin{array}{l}.254^{* *} \\
(.0708)\end{array}$ \\
\hline$\$ 45,001-\$ 50,000$ & $\begin{array}{l}.768^{\star *} \\
(.0839)\end{array}$ & $\begin{array}{l}.530^{\star *} \\
(.0712)\end{array}$ & $\begin{array}{l}.513^{* *} \\
(.0789)\end{array}$ & $\begin{array}{l}.510^{\star *} \\
(.0772)\end{array}$ & $\begin{array}{l}.476^{* *} \\
(.0715)\end{array}$ & $\begin{array}{l}.225^{* *} \\
(.0691)\end{array}$ \\
\hline$\$ 50,001-\$ 55,000$ & $\begin{array}{l}.921^{* *} \\
(.0719)\end{array}$ & $\begin{array}{l}.673^{* *} \\
(.0639)\end{array}$ & $\begin{array}{l}.651^{* *} \\
(.0713)\end{array}$ & $\begin{array}{l}.623^{* *} \\
(.0634)\end{array}$ & $\begin{array}{l}.620^{* *} \\
(.0735)\end{array}$ & $\begin{array}{l}.328^{* *} \\
(.0710)\end{array}$ \\
\hline$\$ 55,001-\$ 60,000$ & $\begin{array}{l}.879^{* *} \\
(.0724)\end{array}$ & $\begin{array}{l}.593^{* *} \\
(.0606)\end{array}$ & $\begin{array}{l}.577^{* *} \\
(.0686)\end{array}$ & $\begin{array}{l}.581^{* *} \\
(.0726)\end{array}$ & $\begin{array}{l}.571^{\star *} \\
(.0737)\end{array}$ & $\begin{array}{l}.284^{* *} \\
(.0713)\end{array}$ \\
\hline$\$ 60,001-\$ 65,000$ & $\begin{array}{l}.958^{* *} \\
(.0948)\end{array}$ & $\begin{array}{l}.677^{* *} \\
(.0798)\end{array}$ & $\begin{array}{l}.634^{* *} \\
(.0868)\end{array}$ & $\begin{array}{l}.626^{* *} \\
(.0865)\end{array}$ & $\begin{array}{c}.661^{* *} \\
(.0734)\end{array}$ & $\begin{array}{l}.334^{* *} \\
(.0712)\end{array}$ \\
\hline$\$ 65,001-\$ 70,000$ & $\begin{array}{l}.898^{* *} \\
(.0844)\end{array}$ & $\begin{array}{l}.580^{* *} \\
(.0764)\end{array}$ & $\begin{array}{l}.580^{* *} \\
(.0752)\end{array}$ & $\begin{array}{l}.543^{* *} \\
(.0851)\end{array}$ & $\begin{array}{l}.592^{* *} \\
(.0734)\end{array}$ & $\begin{array}{l}.286^{* *} \\
(.0712)\end{array}$ \\
\hline \$70,001-\$75,000 & $\begin{array}{l}1.086^{* *} \\
(.0770)\end{array}$ & $\begin{array}{l}.776^{* *} \\
(.0684)\end{array}$ & $\begin{array}{l}.757^{* *} \\
(.0743)\end{array}$ & $\begin{array}{l}.743^{* *} \\
(.0787)\end{array}$ & $\begin{array}{l}.756^{\star *} \\
(.0707)\end{array}$ & $\begin{array}{l}.430^{\star *} \\
(.0688)\end{array}$ \\
\hline \$75,001-\$100,000 & $\begin{array}{l}1.109^{* *} \\
(.0768)\end{array}$ & $\begin{array}{l}.785^{* *} \\
(.0643)\end{array}$ & $\begin{array}{l}.721^{* *} \\
(.0726)\end{array}$ & $\begin{array}{c}.706^{* *} \\
(.0743)\end{array}$ & $\begin{array}{l}.746^{\star *} \\
(.0607)\end{array}$ & $\begin{array}{c}.373^{* *} \\
(.0598)\end{array}$ \\
\hline$\$ 100,001-\$ 200,000$ & $\begin{array}{l}1.129^{* *} \\
(.0754)\end{array}$ & $\begin{array}{l}.810^{\star *} \\
(.0652)\end{array}$ & $\begin{array}{l}.726^{\star *} \\
(.0706)\end{array}$ & $\begin{array}{l}.680^{* *} \\
(.0747)\end{array}$ & $\begin{array}{l}.744^{* *} \\
(.0605)\end{array}$ & $\begin{array}{l}.358^{* *} \\
(.0601)\end{array}$ \\
\hline$\$ 200,001$ or more & $\begin{array}{l}1.127^{* *} \\
(.0874)\end{array}$ & $\begin{array}{l}.810^{* *} \\
(.0774)\end{array}$ & $\begin{array}{l}.715^{* *} \\
(.0786)\end{array}$ & $\begin{array}{l}.628^{* *} \\
(.0841)\end{array}$ & $\begin{array}{l}.676^{* *} \\
(.0715)\end{array}$ & $\begin{array}{l}.277^{* *} \\
(.0703)\end{array}$ \\
\hline Constant & $\begin{array}{c}-.718^{\star *} \\
(.0783)\end{array}$ & $\begin{array}{c}-.262^{* *} \\
(.0645)\end{array}$ & $\begin{array}{c}-1.662^{\star *} \\
(.235)\end{array}$ & $\begin{array}{r}-1.392^{* *} \\
(.0758)\end{array}$ & $\begin{array}{c}-.492^{\star *} \\
(.0549)\end{array}$ & $\begin{array}{c}-1.187^{* *} \\
(.179)\end{array}$ \\
\hline Student race/ethnicity & & $\mathrm{X}$ & & & & $\mathrm{X}$ \\
\hline Out-of-school activities & & & $\mathrm{X}$ & & & $\mathrm{X}$ \\
\hline Parental education & & & & $\mathrm{X}$ & & $\mathrm{X}$ \\
\hline School fixed effects & & & & & $X$ & $\mathrm{X}$ \\
\hline Observations & 10,066 & 10,066 & 10,066 & 10,066 & 10,066 & 10,066 \\
\hline$R^{2}$ & .158 & .250 & .244 & .222 & .051 & .149 \\
\hline Number of schools & & & & & 996 & 996 \\
\hline
\end{tabular}

\section{Comparisons to Income-Based Gaps in Reading and Mathematics}

To put the estimated achievement gaps in perspective, it is useful to compare the income-based science achievement gap to the corresponding income-based mathematics and reading achievement gaps. I find that the income-based achieve- 
ment gap in science is as large as or, in some cases, larger than the corresponding gaps for reading and mathematics. Figure 2 shows coefficients from regressions predicting the income-based science achievement gap and the corresponding mathematics and reading gaps (see Table A2 for exact point estimates of coefficients). As shown, the magnitude of the science gap is consistently larger in magnitude than that for reading or mathematics. As shown in Table A2, these differences are statistically significant across most of the distribution, particularly so for comparisons between science and reading. For instance, at the median $(\$ 50,001-\$ 55,000)$, the science gap is more than $0.2 S D$ larger in magnitude than that for reading or mathematics. Although the ratio of the 50-10 to 90-50 percentile achievement gaps is less than 2 for mathematics and reading, the corresponding ratio is nearly 4 for science. This suggests that science achievement is more sensitive to income differentials in the bottom half of the income distribution than is reading or mathematics achievement.

\section{Extension to First Grade}

Finally, given evidence that achievement gaps can change in the early years of schooling (Fryer \& Levitt, 2004), I compared the income-based science achievement gap in kindergarten to that in first grade (see Fig. A1). Although the magnitude of the coefficients was consistently larger in first grade, the difference was small with $95 \%$ confidence intervals overlapping at each income bracket. In general, the trends observed in kindergarten were also found to hold in first grade. In particular, the gap was larger for the gap between those near the fiftieth percentile

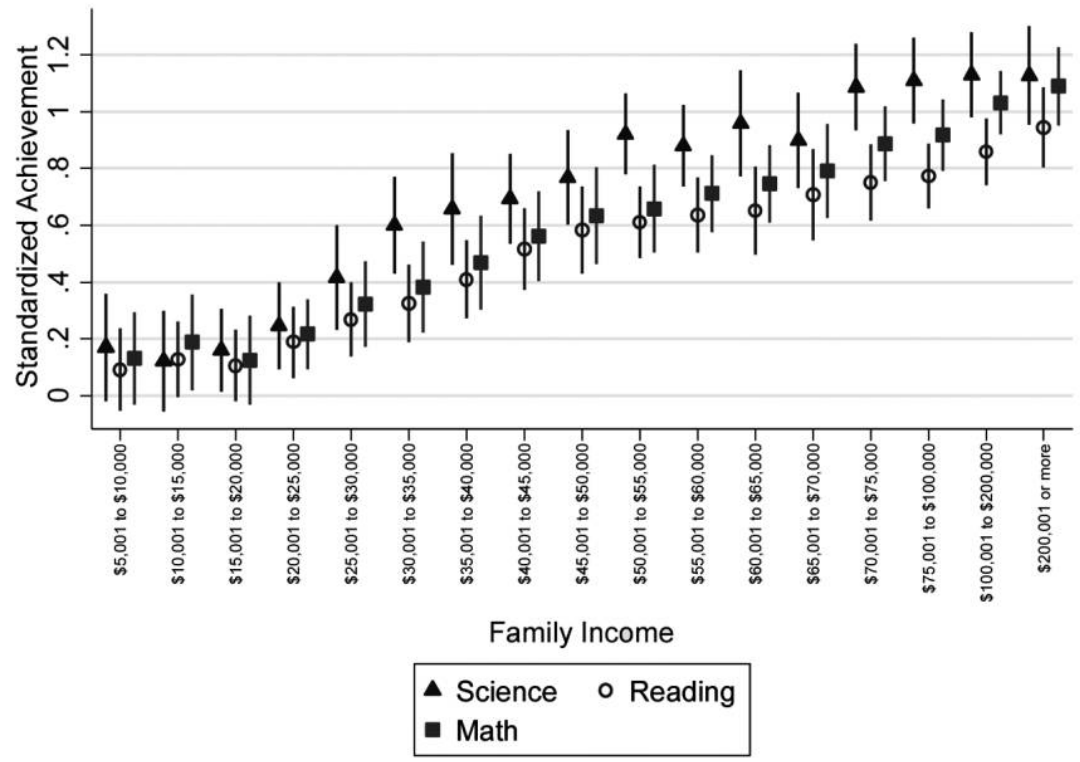

Figure 2. Coefficients from regressions predicting spring kindergarten achievement in science, mathematics, and reading from family income. Bars show $95 \%$ confidence intervals. All estimates weighted and adjusted for ECLS-K:2011's complex sampling design. 
and the tenth percentile compared with that between those near the ninetieth percentile and the fiftieth percentile.

\section{Discussion}

As science continues to grow as a source of economic opportunity and civic importance for both individuals and society, addressing these income-based gaps in science achievement will be an increasingly important issue for policy makers, educators, and other stakeholders. The findings of this study demonstrate that science achievement gaps by family income appear early in the academic trajectory of students. This suggests that the income-based gaps documented in later elementary and secondary school grades, such as those found in the NAEP (National Center for Education Statistics, 2011, 2012a, 2012b), and those that exist in higher education and the workforce are continuations of an early disparity in achievement between students from lower income families and those from more affluent families. Furthermore, the finding that the early income-based science achievement gaps are as large as or, in some cases, larger than the corresponding gaps in reading and mathematics emphasizes the importance of increased attention to early science learning.

The theoretical framing of ecological systems theory provides grounding for understanding the contributors to income-based science achievement gaps as well as the potential policy and practice levers for alleviating such gaps. Ecological systems theory suggests that the root causes of the documented income-based science achievement gaps are likely spread across a number of domains (Bronfenbrenner, 1992; Bronfenbrenner \& Morris, 2006). Like corresponding gaps in mathematics and reading (Quinn, 2015), income-based science achievement gaps are likely influenced by domains such as familial factors (e.g., lower average parental education or scarcer resources to dedicate to a child's learning), community factors (e.g., less availability of out-of-school enrichment activities, higher likelihood of exposure to crime or community disorder, lower achieving neighborhood peers, fewer supports from community organizations), and school factors (e.g., lower quality preschool, underresourced elementary schools, lower achieving school peers, lower quality teachers), among others.

Indeed, the findings of this study, while not able to identify specific causes of science achievement gaps, provide suggestive evidence of the potentially multifaceted nature of the contributors to early science achievement gaps. The results suggest that observed characteristics across a number of the contextual domains posited by ecological systems theory are able to explain meaningful portions of the income-based science achievement gap (Bronfenbrenner, 1992; Bronfenbrenner \& Morris, 2006). For instance, the race/ethnicity of the child represents an individuallevel factor (albeit one that interacts with other contexts and wider aspects of politics and culture) whereas parental education and some of the home-based out-ofschool activities represent explanatory factors in the home and family contexts. Likewise, other measures within the out-of-school activities set of controls account for involvement in neighborhood and community contexts. Finally, the school fixed effects demonstrate the potential role of differences across schools serving students from different family income backgrounds on science achievement gaps. Though 
the correlational nature of this study precludes attributions of causation to any of these contextual domains, the fact that each is predictive of an approximately onethird decrease in the observed income-based achievement gap and that the inclusion of all of them reduces the gap by approximately two thirds points to the multifaceted nature of the income-based science achievement gap.

What, then, can be done to alleviate income-based science achievement gaps and produce more equitable outcomes for students from across the income spectrum? The findings, coupled with the theoretical framings, suggest that a multifaceted approach involving both school-based and out-of-school interventions may hold the most promise. First, general policies and interventions designed to improve the academic outcomes of students from lower income backgrounds would be expected to improve equity in science achievement simultaneously with reading or mathematics achievement. For example, interventions that improve the quality of neighborhoods lived in and schools attended by lower income students have shown promise for increasing academic achievement and future outcomes (Chetty, Friedman, \& Rockoff, 2014; Chetty, Hendren, \& Katz, 2016). Next, specific policy and practice shifts related to both formal and informal science learning may also mitigate income-based science achievement gaps. For example, attention might be given to the time spent on science (Bassok et al., 2016; Blank, 2013; Marx \& Harris, 2006; Phillips, Gormley, \& Lowenstein, 2009; Sackes, Trundle, \& Bell, 2013; Sackes, Trundle, Bell, \& O'Connell, 2011; Tu, 2006), the capacity of teachers and school leaders to teach science (Bianchini, Dwyer, Brenner, \& Wearly, 2015), and the ways in which science is taught and integrated with other subjects (Hayes \& Trexler, 2016). The recently developed Next Generation Science Standards and the National Research Council's corresponding framework on $\mathrm{K}-12$ science instruction provide some grounding for such shifts in instructional practice around science. They do this through their emphasis on a limited number of disciplinary core ideas, a number of cross-cutting concepts, and a focus on the practices of doing science and engineering work (NGSS Lead States, 2013; Quinn et al., 2012). Finally, given the evidence on the role of out-of-school environments (Coleman et al., 1966; Rothstein, 2004), an emphasis on increasing the capacity of families and community contexts to support science learning in informal environments may also hold potential. For example, increasing access to settings like science museums and opportunities for parental interaction around science may improve equity in science achievement (Berkowitz et al., 2015; Paris, Yambor, \& Packard, 1998; Suter, 2014).

\section{Conclusion}

Science proficiency is an increasingly important skill for both economic and civic engagement. Unfortunately, students from lower income backgrounds tend to have lower science achievement, on average, than their more affluent peers - a result that may affect their ability to fully engage in scientific discourse. This study has addressed this important policy problem by focusing on income-based science achievement gaps in the earliest grades of formal schooling, an area previously lacking systematic research. The findings point to significant achievement gaps by income in the earliest grades but demonstrate that these gaps can be explained 
by both in-school and out-of-school explanatory factors. The documentation of this achievement gap and the explanatory role of both out-of-school and school factors point to the need for further research on interventions designed to reduce income-based science achievement gaps. In particular, rigorous work that identifies the causal effect of interventions designed to remediate these gaps is needed to inform policy and practice. With such information, policy makers, educators, and other stakeholders can begin devising clear directions for improving equity in science achievement.

\section{Appendix}

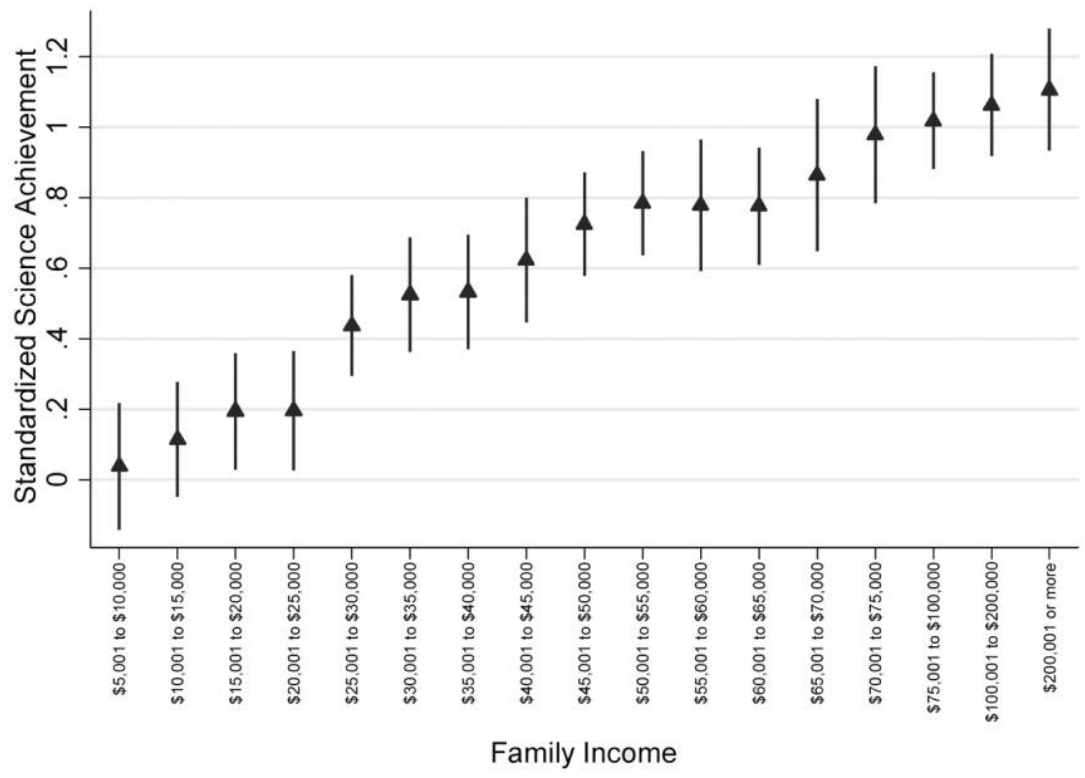

Figure A1. Income-based science achievement gap in spring of first grade without controls. Bars show $95 \%$ confidence intervals. All estimates weighted and adjusted for ECLS-K:2011's complex sampling design.

Table A1. Results from Regressions Predicting Standardized Science Achievement in Spring of Kindergarten from Family Income Categories with All Regression Coefficients

\begin{tabular}{|c|c|c|c|c|c|c|}
\hline & $\begin{array}{l}\text { Raw } \\
\text { Gaps } \\
(1)\end{array}$ & $\begin{array}{l}\text { Race/ } \\
\text { Ethnicity } \\
\text { Controls } \\
\text { (2) }\end{array}$ & $\begin{array}{c}\text { Out-of-School } \\
\text { Activities } \\
\text { (3) }\end{array}$ & $\begin{array}{c}\text { Parental } \\
\text { Education } \\
\quad(4)\end{array}$ & $\begin{array}{l}\text { School } \\
\text { Fixed } \\
\text { Effects } \\
(5)\end{array}$ & $\begin{array}{c}\text { All } \\
\text { Controls } \\
(6)\end{array}$ \\
\hline$\$ 5,001-\$ 10,000$ & $\begin{array}{l}.170 \\
(.0955)\end{array}$ & $\begin{array}{l}.133 \\
(.0823)\end{array}$ & $\begin{array}{l}.156 \\
(.0895)\end{array}$ & $\begin{array}{l}.168 \\
(.0923)\end{array}$ & $\begin{array}{l}.130 \\
(.0717)\end{array}$ & $\begin{array}{l}.111 \\
(.0683)\end{array}$ \\
\hline$\$ 10,001-\$ 15,000$ & $\begin{array}{l}.121 \\
(.0894)\end{array}$ & $\begin{array}{l}.113 \\
(.0856)\end{array}$ & $\begin{array}{l}.0848 \\
(.0866)\end{array}$ & $\begin{array}{l}.132 \\
(.0902)\end{array}$ & $\begin{array}{l}.153^{\star} \\
(.0662)\end{array}$ & $\begin{array}{l}.104 \\
(.0632)\end{array}$ \\
\hline$\$ 15,001-\$ 20,000$ & $\begin{array}{l}.160^{*} \\
(.0733)\end{array}$ & $\begin{array}{l}.112 \\
(.0722)\end{array}$ & $\begin{array}{l}.135 \\
(.0746)\end{array}$ & $\begin{array}{l}.120 \\
(.0726)\end{array}$ & $\begin{array}{c}.148^{*} \\
(.0655)\end{array}$ & $\begin{array}{l}.101 \\
(.0625)\end{array}$ \\
\hline
\end{tabular}


Table A1. (Continued)

\begin{tabular}{|c|c|c|c|c|c|c|}
\hline & $\begin{array}{c}\text { Raw } \\
\text { Gaps } \\
(1)\end{array}$ & $\begin{array}{c}\text { Race/ } \\
\text { Ethnicity } \\
\text { Controls } \\
(2)\end{array}$ & $\begin{array}{l}\text { Out-of-School } \\
\text { Activities } \\
\text { (3) }\end{array}$ & $\begin{array}{l}\text { Parental } \\
\text { Education } \\
\quad(4)\end{array}$ & $\begin{array}{l}\text { School } \\
\text { Fixed } \\
\text { Effects } \\
(5)\end{array}$ & $\begin{array}{c}\text { All } \\
\text { Controls } \\
(6)\end{array}$ \\
\hline$\$ 20,001-\$ 25,000$ & $\begin{array}{l}.246^{* *} \\
(.0770)\end{array}$ & $\begin{array}{l}.195^{* \star} \\
(.0662)\end{array}$ & $\begin{array}{l}.149^{*} \\
(.0752)\end{array}$ & $\begin{array}{l}.185^{*} \\
(.0775)\end{array}$ & $\begin{array}{l}.241^{* *} \\
(.0635)\end{array}$ & $\begin{array}{l}.144^{*} \\
(.0607)\end{array}$ \\
\hline$\$ 25,001-\$ 30,000$ & $\begin{array}{l}.416^{\star *} \\
(.0936)\end{array}$ & $\begin{array}{l}.338^{* *} \\
(.0811)\end{array}$ & $\begin{array}{l}.261^{\star *} \\
(.0911)\end{array}$ & $\begin{array}{c}.267^{* *} \\
(.0844)\end{array}$ & $\begin{array}{l}.277^{* *} \\
(.0682)\end{array}$ & $\begin{array}{l}.146^{*} \\
(.0655)\end{array}$ \\
\hline$\$ 30,001-\$ 35,000$ & $\begin{array}{l}.600^{\star *} \\
(.0859)\end{array}$ & $\begin{array}{l}.451^{\star *} \\
(.0749)\end{array}$ & $\begin{array}{l}.429^{\star *} \\
(.0814)\end{array}$ & $\begin{array}{l}.414^{* *} \\
(.0858)\end{array}$ & $\begin{array}{l}.449^{* *} \\
(.0685)\end{array}$ & $\begin{array}{l}.288^{* *} \\
(.0658)\end{array}$ \\
\hline$\$ 35,001-\$ 40,000$ & $\begin{array}{l}.657^{\star *} \\
(.0995)\end{array}$ & $\begin{array}{l}.485^{* *} \\
(.0874)\end{array}$ & $\begin{array}{l}.422^{\star *} \\
(.0937)\end{array}$ & $\begin{array}{c}.425^{* *} \\
(.0984)\end{array}$ & $\begin{array}{l}.493^{\star *} \\
(.0685)\end{array}$ & $\begin{array}{c}.267^{* *} \\
(.0660)\end{array}$ \\
\hline$\$ 40,001-\$ 45,000$ & $\begin{array}{l}.693^{* *} \\
(.0796)\end{array}$ & $\begin{array}{l}.491^{* *} \\
(.0682)\end{array}$ & $\begin{array}{l}.457^{* *} \\
(.0720)\end{array}$ & $\begin{array}{l}.469^{* *} \\
(.0783)\end{array}$ & $\begin{array}{l}.470^{\star *} \\
(.0735)\end{array}$ & $\begin{array}{l}.254^{* *} \\
(.0708)\end{array}$ \\
\hline$\$ 45,001-\$ 50,000$ & $\begin{array}{l}.768^{\star *} \\
(.0839)\end{array}$ & $\begin{array}{l}.530^{\star *} \\
(.0712)\end{array}$ & $\begin{array}{l}.513^{\star *} \\
(.0789)\end{array}$ & $\begin{array}{l}.510^{* *} \\
(.0772)\end{array}$ & $\begin{array}{l}.476^{* *} \\
(.0715)\end{array}$ & $\begin{array}{l}.225^{* *} \\
(.0691)\end{array}$ \\
\hline$\$ 50,001-\$ 55,000$ & $\begin{array}{l}.921^{\star *} \\
(.0719)\end{array}$ & $\begin{array}{l}.673^{* *} \\
(.0639)\end{array}$ & $\begin{array}{l}.651^{* *} \\
(.0713)\end{array}$ & $\begin{array}{l}.623^{* *} \\
(.0634)\end{array}$ & $\begin{array}{l}.620^{* *} \\
(.0735)\end{array}$ & $\begin{array}{l}.328^{\star *} \\
(.0710)\end{array}$ \\
\hline$\$ 55,001-\$ 60,000$ & $\begin{array}{l}.879^{\star *} \\
(.0724)\end{array}$ & $\begin{array}{l}.593^{* *} \\
(.0606)\end{array}$ & $\begin{array}{l}.577^{* *} \\
(.0686)\end{array}$ & $\begin{array}{c}.581^{* \star} \\
(.0726)\end{array}$ & $\begin{array}{l}.571^{* *} \\
(.0737)\end{array}$ & $\begin{array}{l}.284^{* *} \\
(.0713)\end{array}$ \\
\hline$\$ 60,001-\$ 65,000$ & $\begin{array}{l}.958^{\star *} \\
(.0948)\end{array}$ & $\begin{array}{l}.677^{* *} \\
(.0798)\end{array}$ & $\begin{array}{l}.634^{* *} \\
(.0868)\end{array}$ & $\begin{array}{c}.626^{\star *} \\
(.0865)\end{array}$ & $\begin{array}{l}.661^{* *} \\
(.0734)\end{array}$ & $\begin{array}{l}.334^{* *} \\
(.0712)\end{array}$ \\
\hline$\$ 65,001-\$ 70,000$ & $\begin{array}{l}.898^{\star *} \\
(.0844)\end{array}$ & $\begin{array}{l}.580^{\star *} \\
(.0764)\end{array}$ & $\begin{array}{l}.580^{\star *} \\
(.0752)\end{array}$ & $\begin{array}{l}.543^{* *} \\
(.0851)\end{array}$ & $\begin{array}{l}.592^{\star *} \\
(.0734)\end{array}$ & $\begin{array}{l}.286^{\star *} \\
(.0712)\end{array}$ \\
\hline \$70,001-\$75,000 & $\begin{array}{l}1.086^{* *} \\
(.0770)\end{array}$ & $\begin{array}{l}.776^{* *} \\
(.0684)\end{array}$ & $\begin{array}{l}.757^{* *} \\
(.0743)\end{array}$ & $\begin{array}{l}.743^{* *} \\
(.0787)\end{array}$ & $\begin{array}{l}.756^{\star *} \\
(.0707)\end{array}$ & $\begin{array}{l}.430^{\star *} \\
(.0688)\end{array}$ \\
\hline$\$ 75,001-\$ 100,000$ & $\begin{array}{l}1.109^{\star *} \\
(.0768)\end{array}$ & $\begin{array}{l}.785^{* *} \\
(.0643)\end{array}$ & $\begin{array}{l}.721^{* \star} \\
(.0726)\end{array}$ & $\begin{array}{l}.706^{\star *} \\
(.0743)\end{array}$ & $\begin{array}{l}.746^{* *} \\
(.0607)\end{array}$ & $\begin{array}{l}.373^{* \star} \\
(.0598)\end{array}$ \\
\hline$\$ 100,001-\$ 200,000$ & $\begin{array}{l}1.129^{\star *} \\
(.0754)\end{array}$ & $\begin{array}{l}.810^{* *} \\
(.0652)\end{array}$ & $\begin{array}{l}.726^{\star *} \\
(.0706)\end{array}$ & $\begin{array}{c}.680^{\star *} \\
(.0747)\end{array}$ & $\begin{array}{l}.744^{* *} \\
(.0605)\end{array}$ & $\begin{array}{l}.358^{* *} \\
(.0601)\end{array}$ \\
\hline$\$ 200,001$ or more & $\begin{array}{l}1.127^{* *} \\
(.0874)\end{array}$ & $\begin{array}{l}.810^{* *} \\
(.0774)\end{array}$ & $\begin{array}{l}.715^{* *} \\
(.0786)\end{array}$ & $\begin{array}{c}.628^{* *} \\
(.0841)\end{array}$ & $\begin{array}{l}.676^{* *} \\
(.0715)\end{array}$ & $\begin{array}{l}.277^{* *} \\
(.0703)\end{array}$ \\
\hline \multicolumn{7}{|l|}{ Student race: } \\
\hline Black & & $\begin{array}{c}-.575^{* *} \\
(.0589)\end{array}$ & & & & $\begin{array}{c}-.337^{\star *} \\
(.0386)\end{array}$ \\
\hline Hispanic & & $\begin{array}{c}-.745^{\star *} \\
(.0444)\end{array}$ & & & & $\begin{array}{c}-.330^{\star *} \\
(.0296)\end{array}$ \\
\hline Asian & & $\begin{array}{c}-.524^{* *} \\
(.0638)\end{array}$ & & & & $\begin{array}{c}-.309^{* *} \\
(.0419)\end{array}$ \\
\hline Other & & $\begin{array}{c}-.0863 \\
(.0515)\end{array}$ & & & & $\begin{array}{c}-.0646 \\
(.0368)\end{array}$ \\
\hline \multicolumn{7}{|l|}{ Tell stories to child: } \\
\hline Once or twice a week & & & $\begin{array}{l}.115 \\
(.0657)\end{array}$ & & & $\begin{array}{c}.0864 \\
(.0590)\end{array}$ \\
\hline 3-6 times a week & & & $\begin{array}{l}.105 \\
(.0654)\end{array}$ & & & $\begin{array}{l}.0495 \\
(.0599)\end{array}$ \\
\hline Every day & & & $\begin{array}{l}.147^{*} \\
(.0664)\end{array}$ & & & $\begin{array}{l}.0783 \\
(.0600)\end{array}$ \\
\hline \multicolumn{7}{|l|}{ Sing songs with child: } \\
\hline Once or twice a week & & & $\begin{array}{l}.00825 \\
(.0647)\end{array}$ & & & $\begin{array}{c}-.0196 \\
(.0483)\end{array}$ \\
\hline 3-6 times a week & & & $\begin{array}{l}.0425 \\
(.0680)\end{array}$ & & & $\begin{array}{c}-.00485 \\
(.0488)\end{array}$ \\
\hline Every day & & & $\begin{array}{l}.0405 \\
(.0672)\end{array}$ & & & $\begin{array}{c}-.0232 \\
(.0484)\end{array}$ \\
\hline \multicolumn{7}{|l|}{ Do arts and crafts: } \\
\hline Once or twice a week & & & $\begin{array}{c}.0900 \\
(.0639)\end{array}$ & & & $\begin{array}{l}.00292 \\
(.0485)\end{array}$ \\
\hline
\end{tabular}


Table A1. (Continued)

\begin{tabular}{|c|c|c|c|c|c|c|}
\hline & $\begin{array}{c}\text { Raw } \\
\text { Gaps } \\
(1)\end{array}$ & $\begin{array}{l}\text { Race/ } \\
\text { Ethnicity } \\
\text { Controls } \\
\text { (2) }\end{array}$ & $\begin{array}{c}\text { Out-of-School } \\
\text { Activities } \\
\text { (3) }\end{array}$ & $\begin{array}{l}\text { Parental } \\
\text { Education } \\
\quad(4)\end{array}$ & $\begin{array}{l}\text { School } \\
\text { Fixed } \\
\text { Effects } \\
(5)\end{array}$ & $\begin{array}{c}\text { All } \\
\text { Controls } \\
(6)\end{array}$ \\
\hline $3^{-6}$ times a week & & & $\begin{array}{l}.0889 \\
(.0593)\end{array}$ & & & $\begin{array}{l}.0179 \\
(.0498)\end{array}$ \\
\hline Every day & & & $\begin{array}{l}-.0322 \\
(.0623)\end{array}$ & & & $\begin{array}{r}-.0567 \\
(.0511)\end{array}$ \\
\hline \multicolumn{7}{|l|}{ Play games or puzzles: } \\
\hline Once or twice a week & & & $\begin{array}{l}.308^{* *} \\
(.0748)\end{array}$ & & & $\begin{array}{l}.147^{*} \\
(.0602)\end{array}$ \\
\hline $3^{-6}$ times a week & & & $\begin{array}{l}.283^{* *} \\
(.0789)\end{array}$ & & & $\begin{array}{l}.128^{*} \\
(.0610)\end{array}$ \\
\hline Every day & & & $\begin{array}{l}.156^{*} \\
(.0742)\end{array}$ & & & $\begin{array}{l}.0517 \\
(.0623)\end{array}$ \\
\hline \multicolumn{7}{|c|}{$\begin{array}{l}\text { Talk about nature or do science } \\
\text { projects: }\end{array}$} \\
\hline Once or twice a week & & & $\begin{array}{l}.191^{* *} \\
(.0310)\end{array}$ & & & $\begin{array}{l}.104^{* *} \\
(.0266)\end{array}$ \\
\hline $3-6$ times a week & & & $\begin{array}{l}.318^{* *} \\
(.0351)\end{array}$ & & & $\begin{array}{l}.211^{* *} \\
(.0312)\end{array}$ \\
\hline Every day & & & $\begin{array}{l}.348^{* *} \\
(.0476)\end{array}$ & & & $\begin{array}{l}.256^{* *} \\
(.0363)\end{array}$ \\
\hline \multicolumn{7}{|l|}{ Build things: } \\
\hline Once or twice a week & & & $\begin{array}{c}-.00710 \\
(.0341)\end{array}$ & & & $\begin{array}{l}-.0168 \\
(.0276)\end{array}$ \\
\hline $3-6$ times a week & & & $\begin{array}{l}-.00813 \\
(.0387)\end{array}$ & & & $\begin{array}{l}-.0177 \\
(.0305)\end{array}$ \\
\hline Every day & & & $\begin{array}{l}-.0288 \\
(.0404)\end{array}$ & & & $\begin{array}{l}-.0312 \\
(.0337)\end{array}$ \\
\hline \multicolumn{7}{|c|}{$\begin{array}{l}\text { Practice reading, writing, or } \\
\text { numbers: }\end{array}$} \\
\hline Once or twice a week & & & $\begin{array}{l}.0793 \\
(.196)\end{array}$ & & & $\begin{array}{l}.0607 \\
(.144)\end{array}$ \\
\hline 3-6 times a week & & & $\begin{array}{l}.0572 \\
(.206)\end{array}$ & & & $\begin{array}{l}.0565 \\
(.142)\end{array}$ \\
\hline Every day & & & $\begin{array}{l}-.00917 \\
(.204)\end{array}$ & & & $\begin{array}{l}.0194 \\
(.142)\end{array}$ \\
\hline \multicolumn{7}{|l|}{ Read books to child: } \\
\hline 3-6 times a week & & & $\begin{array}{l}.203^{* *} \\
(.0333)\end{array}$ & & & $\begin{array}{l}.0848^{* *} \\
(.0315)\end{array}$ \\
\hline Every day & & & $\begin{array}{l}.310^{* *} \\
(.0372)\end{array}$ & & & $\begin{array}{l}.149^{* *} \\
(.0331)\end{array}$ \\
\hline \multicolumn{7}{|l|}{ Look at picture books: } \\
\hline Once or twice a week & & & $\begin{array}{l}-.100 \\
(.0746)\end{array}$ & & & $\begin{array}{l}-.127 \\
(.0660)\end{array}$ \\
\hline 3-6 times a week & & & $\begin{aligned}-.00127 \\
(.0743)\end{aligned}$ & & & $\begin{array}{l}-.0806 \\
(.0650)\end{array}$ \\
\hline Every day & & & $\begin{array}{l}.0275 \\
(.0763)\end{array}$ & & & $\begin{array}{l}-.0699 \\
(.0648)\end{array}$ \\
\hline Visited library & & & $\begin{array}{l}.0339 \\
(.0234)\end{array}$ & & & $\begin{array}{l}.0440^{*} \\
(.0183)\end{array}$ \\
\hline Visited bookstore & & & $\begin{array}{r}-.00135 \\
(.0229)\end{array}$ & & & $\begin{array}{l}-.00385 \\
(.0181)\end{array}$ \\
\hline $\begin{array}{l}\text { Went to play, concert, or } \\
\text { show }\end{array}$ & & & $\begin{array}{l}-.00590 \\
(.0197)\end{array}$ & & & $\begin{array}{l}-.0322 \\
(.0179)\end{array}$ \\
\hline
\end{tabular}


Table A1. (Continued)

\begin{tabular}{|c|c|c|c|c|c|c|}
\hline & $\begin{array}{c}\text { Raw } \\
\text { Gaps } \\
(1)\end{array}$ & $\begin{array}{c}\text { Race/ } \\
\text { Ethnicity } \\
\text { Controls } \\
\text { (2) }\end{array}$ & $\begin{array}{l}\text { Out-of-School } \\
\text { Activities } \\
\text { (3) }\end{array}$ & $\begin{array}{c}\text { Parental } \\
\text { Education } \\
\text { (4) }\end{array}$ & $\begin{array}{l}\text { School } \\
\text { Fixed } \\
\text { Effects } \\
(5)\end{array}$ & $\begin{array}{c}\text { All } \\
\text { Controls } \\
(6)\end{array}$ \\
\hline $\begin{array}{l}\text { Visited art gallery, museum, } \\
\text { or historical site }\end{array}$ & & & $\begin{array}{l}.0660^{* *} \\
(.0200)\end{array}$ & & & $\begin{array}{l}.0544^{* *} \\
(.0189)\end{array}$ \\
\hline $\begin{array}{l}\text { Visited a zoo, aquarium, or } \\
\text { petting farm }\end{array}$ & & & $\begin{array}{l}-.0905^{\star *} \\
(.0228)\end{array}$ & & & $\begin{array}{l}-.0624^{* *} \\
(.0184)\end{array}$ \\
\hline Child uses home computer & & & $\begin{array}{l}.189^{* *} \\
(.0249)\end{array}$ & & & $\begin{array}{l}.126^{* *} \\
(.0213)\end{array}$ \\
\hline $\begin{array}{l}\text { Participated in clubs or } \\
\text { recreational programs }\end{array}$ & & & $\begin{array}{l}.128^{* *} \\
(.0263)\end{array}$ & & & $\begin{array}{l}.0353 \\
(.0258)\end{array}$ \\
\hline Participated in music lessons & & & $\begin{array}{l}.0735^{* *} \\
(.0251)\end{array}$ & & & $\begin{array}{l}.0950^{* *} \\
(.0293)\end{array}$ \\
\hline Participated in drama classes & & & $\begin{array}{l}.175^{* *} \\
(.0525)\end{array}$ & & & $\begin{array}{l}.0992 \\
(.0587)\end{array}$ \\
\hline $\begin{array}{l}\text { Participated in art classes } \\
\text { or lessons }\end{array}$ & & & $\begin{array}{l}.0497 \\
(.0323)\end{array}$ & & & $\begin{array}{l}.0575 \\
(.0305)\end{array}$ \\
\hline Participated in performing arts & & & $\begin{array}{l}.00198 \\
(.0252)\end{array}$ & & & $\begin{array}{l}.0112 \\
(.0248)\end{array}$ \\
\hline $\begin{array}{c}\text { Participated in non-English } \\
\text { language instruction }\end{array}$ & & & $\begin{array}{l}-.0681 \\
(.0418)\end{array}$ & & & $\begin{array}{l}-.0177 \\
(.0336)\end{array}$ \\
\hline Minutes spent reading & & & $\begin{array}{l}-.000710 \\
(.00112)\end{array}$ & & & $\begin{array}{l}.00204^{*} \\
(.000870)\end{array}$ \\
\hline Number of children books & & & & & & \\
\hline in house & & & $\begin{array}{l}.000634^{* *} \\
(.000123)\end{array}$ & & & $\begin{array}{l}.000359^{* *} \\
(6.42 \mathrm{e}-05)\end{array}$ \\
\hline Nonparental care for pre- $\mathrm{K}$ & & & $\begin{array}{l}.120^{\star *} \\
(.0340)\end{array}$ & & & $\begin{array}{l}.0819^{* *} \\
(.0280)\end{array}$ \\
\hline Center-based care for pre- $\mathrm{K}$ & & & $\begin{array}{l}.128^{* *} \\
(.0332)\end{array}$ & & & $\begin{array}{l}.0612^{* *} \\
(.0237)\end{array}$ \\
\hline Head Start care for pre-K & & & $\begin{array}{l}-.122^{* *} \\
(.0377)\end{array}$ & & & $\begin{array}{c}-.0651^{*} \\
(.0298)\end{array}$ \\
\hline $\begin{array}{l}\text { Parent education: } \\
\text { 9th-12th grade }\end{array}$ & & & & $\begin{array}{l}.387^{* *} \\
(.0721)\end{array}$ & & $\begin{array}{l}.220^{\star *} \\
(.0568)\end{array}$ \\
\hline $\begin{array}{l}\text { High school diploma or } \\
\text { equivalent }\end{array}$ & & & & $\begin{array}{l}.755^{* *} \\
(.0584)\end{array}$ & & $\begin{array}{l}.409^{* *} \\
(.0530)\end{array}$ \\
\hline Vocational/technical program & & & & $\begin{array}{l}.947^{* *} \\
(.0683)\end{array}$ & & $\begin{array}{l}.539^{* *} \\
(.0620)\end{array}$ \\
\hline Some college & & & & $\begin{array}{l}.972^{* *} \\
(.0579)\end{array}$ & & $\begin{array}{l}.511^{* *} \\
(.0539)\end{array}$ \\
\hline Bachelor's degree & & & & $\begin{array}{l}1.168^{* *} \\
(.0560)\end{array}$ & & $\begin{array}{l}.633^{* *} \\
(.0567)\end{array}$ \\
\hline $\begin{array}{l}\text { Graduate/professional } \\
\text { school- no degree }\end{array}$ & & & & $\begin{array}{l}1.375^{* *} \\
(.0809)\end{array}$ & & $\begin{array}{l}.725^{* *} \\
(.0796)\end{array}$ \\
\hline Master's degree or higher & & & & $\begin{array}{l}1.266^{* *} \\
(.0591)\end{array}$ & & $\begin{array}{l}.683^{* *} \\
(.0600)\end{array}$ \\
\hline Constant & $\begin{array}{l}-.718^{* *} \\
(.0783)\end{array}$ & $\begin{array}{l}-.262^{* *} \\
(.0645)\end{array}$ & $\begin{array}{c}-1.662^{* *} \\
(.235)\end{array}$ & $\begin{array}{r}-1.392^{* *} \\
(.0758)\end{array}$ & $\begin{array}{l}-.492^{* *} \\
(.0549)\end{array}$ & $\begin{array}{c}-1.187^{* *} \\
(.179)\end{array}$ \\
\hline
\end{tabular}


Table A1. (Continued)

\begin{tabular}{|c|c|c|c|c|c|c|}
\hline & \multicolumn{3}{|c|}{ Race/ } & \multicolumn{3}{|c|}{ School } \\
\hline & $\begin{array}{c}\text { Raw } \\
\text { Gaps } \\
(1)\end{array}$ & $\begin{array}{l}\text { Ethnicity } \\
\text { Controls } \\
\text { (2) }\end{array}$ & $\begin{array}{c}\text { Out-of-School } \\
\text { Activities } \\
\text { (3) }\end{array}$ & $\begin{array}{c}\text { Parental } \\
\text { Education } \\
\text { (4) }\end{array}$ & $\begin{array}{l}\text { Fixed } \\
\text { Effects } \\
(5)\end{array}$ & $\begin{array}{c}\text { All } \\
\text { Controls } \\
\text { (6) }\end{array}$ \\
\hline Observations & 10,066 & 10,066 & 10,066 & 10,066 & 10,066 & 10,066 \\
\hline$R^{2}$ & .158 & .250 & .244 & .222 & .051 & .149 \\
\hline Number of schools & & & & & 996 & 996 \\
\hline
\end{tabular}

Note.-Standard errors in parentheses. All estimates adjusted for the sampling design of the ECLS-K:2011 using weights and Taylor series linearization of standard errors.

$$
\begin{aligned}
& { }^{*} p<05 \\
& { }^{*} p<.01
\end{aligned}
$$

Table A2. Results from Regressions Predicting Standardized Science, Reading, and Mathe-

\begin{tabular}{|c|c|c|c|c|c|}
\hline & \multirow{2}{*}{$\begin{array}{l}\text { Science } \\
\text { (1) }\end{array}$} & \multirow{2}{*}{$\begin{array}{l}\text { Reading } \\
\text { (2) }\end{array}$} & \multirow{2}{*}{$\begin{array}{l}\text { Mathematics } \\
\text { (3) }\end{array}$} & \multicolumn{2}{|c|}{$\begin{array}{l}\text { Significance of Difference } \\
\text { on } t \text { Test for Columns }\end{array}$} \\
\hline & & & & $1 \mathrm{~V} 2$ & $1 \mathrm{v} 3$ \\
\hline$\$ 5,001-\$ 10,000$ & $\begin{array}{l}.170 \\
(.0955)\end{array}$ & $\begin{array}{l}.0910 \\
(.0733)\end{array}$ & $\begin{array}{l}.132 \\
(.0826)\end{array}$ & & \\
\hline$\$ 10,001-\$ 15,000$ & $\begin{array}{l}.121 \\
(.0894)\end{array}$ & $\begin{array}{l}.128 \\
(.0667)\end{array}$ & $\begin{array}{l}.188^{\star} \\
(.0854)\end{array}$ & & \\
\hline$\$ 15,001-\$ 20,000$ & $\begin{array}{l}.160^{*} \\
(.0733)\end{array}$ & $\begin{array}{l}.106 \\
(.0635)\end{array}$ & $\begin{array}{l}.125 \\
(.0789)\end{array}$ & & \\
\hline$\$ 20,001-\$ 25,000$ & $\begin{array}{l}.246^{* *} \\
(.0770)\end{array}$ & $\begin{array}{l}.188^{\star *} \\
(.0637)\end{array}$ & $\begin{array}{l}.217^{* *} \\
(.0623)\end{array}$ & & \\
\hline$\$ 25,001-\$ 30,000$ & $\begin{array}{l}.416^{\star *} \\
(.0936)\end{array}$ & $\begin{array}{l}.268^{\star *} \\
(.0658)\end{array}$ & $\begin{array}{l}.322^{\star *} \\
(.0763)\end{array}$ & & \\
\hline$\$ 30,001-\$ 35,000$ & $\begin{array}{l}.600^{* *} \\
(.0859)\end{array}$ & $\begin{array}{l}.324^{\star *} \\
(.0689)\end{array}$ & $\begin{array}{l}.382^{* *} \\
(.0812)\end{array}$ & * & + \\
\hline$\$ 35,001-\$ 40,000$ & $\begin{array}{l}.657^{* *} \\
(.0995)\end{array}$ & $\begin{array}{l}.409^{* *} \\
(.0698)\end{array}$ & $\begin{array}{l}.468^{* *} \\
(.0839)\end{array}$ & * & \\
\hline$\$ 40,001-\$ 45,000$ & $\begin{array}{l}.693^{* *} \\
(.0796)\end{array}$ & $\begin{array}{l}.516^{\star *} \\
(.0724)\end{array}$ & $\begin{array}{l}.561^{\star *} \\
(.0796)\end{array}$ & + & \\
\hline$\$ 45,001-\$ 50,000$ & $\begin{array}{l}.768^{\star *} \\
(.0839)\end{array}$ & $\begin{array}{l}.583^{* *} \\
(.0773)\end{array}$ & $\begin{array}{l}.633^{* *} \\
(.0861)\end{array}$ & & \\
\hline$\$ 50,001-\$ 55,000$ & $\begin{array}{l}.921^{\star *} \\
(.0719)\end{array}$ & $\begin{array}{l}.610^{* *} \\
(.0635)\end{array}$ & $\begin{array}{l}.658^{\star *} \\
(.0777)\end{array}$ & * & * \\
\hline$\$ 55,001-\$ 60,000$ & $\begin{array}{l}.879^{* *} \\
(.0724)\end{array}$ & $\begin{array}{l}.636^{* *} \\
(.0661)\end{array}$ & $\begin{array}{l}.711^{* *} \\
(.0684)\end{array}$ & * & + \\
\hline$\$ 60,001-\$ 65,000$ & $\begin{array}{l}.958^{* *} \\
(.0948)\end{array}$ & $\begin{array}{l}.651^{* *} \\
(.0785)\end{array}$ & $\begin{array}{l}.746^{* *} \\
(.0688)\end{array}$ & * & + \\
\hline$\$ 65,001-\$ 70,000$ & $\begin{array}{l}.898^{\star *} \\
(.0844)\end{array}$ & $\begin{array}{l}.707^{* *} \\
(.0810)\end{array}$ & $\begin{array}{l}.791^{\star *} \\
(.0838)\end{array}$ & & \\
\hline$\$ 70,001-\$ 75,000$ & $\begin{array}{l}1.086^{* *} \\
(.0770)\end{array}$ & $\begin{array}{l}.750^{\star *} \\
(.0680)\end{array}$ & $\begin{array}{l}.886^{\star *} \\
(.0670)\end{array}$ & * & * \\
\hline$\$ 75,001-\$ 100,000$ & $\begin{array}{l}1.109^{* *} \\
(.0768)\end{array}$ & $\begin{array}{l}.772^{* *} \\
(.0574)\end{array}$ & $\begin{array}{l}.917^{* *} \\
(.0635)\end{array}$ & * & + \\
\hline$\$ 100,001-\$ 200,000$ & $\begin{array}{l}1.129^{\star *} \\
(.0754)\end{array}$ & $\begin{array}{l}.858^{\star *} \\
(.0594)\end{array}$ & $\begin{array}{l}1.031^{* *} \\
(.0567)\end{array}$ & * & \\
\hline
\end{tabular}
matics Achievement in Spring of Kindergarten from Family Income Categories 
Table A2. (Continued)

\begin{tabular}{lcccc}
\hline & Science & Reading & Mathematics \\
$(1)$ & $(2)$ & $(3)$ & \multicolumn{2}{c}{$\begin{array}{c}\text { Significance of Difference } \\
\text { on } t \text { Test for Columns }\end{array}$} \\
\cline { 5 - 5 } \$200,001 or more & $1.127^{* *}$ & $.944^{* *}$ & $1.089^{* *}$ & $1 \mathrm{~V} 2$ \\
Constant & $(.0874)$ & $(.0713)$ & $(.0695)$ & + \\
Observations & $-.718^{* *}$ & $-.497^{* *}$ & $-.600^{* *}$ & \\
$R^{2}$ & $(.0783)$ & $(.0481)$ & $(.0542)$ & \\
\hline
\end{tabular}

Note.-Standard errors in parentheses. All estimates adjusted for the sampling design of the ECLS-K:2011 using weights and Taylor series linearization of standard errors. Sample size varies for mathematics outcome due to additional missing data on the mathematics achievement test.

$+p<.10$

${ }^{*} p<.05$.

** $p<.01$.

\section{Note}

F. Chris Curran is assistant professor of public policy at the School of Public Policy, University of Maryland, Baltimore County. Correspondence may be sent to 411 Public Policy Building, 1000 Hilltop Circle, Baltimore, MD 21225. E-mail: curranfc@umbc.edu.

\section{References}

ACT. (2012). Do race/ethnicity-based student achievement gaps grow over time? (Issue Brief for ACT Research and Policy). Retrieved from https://forms.act.org/research/policymakers/pdf /RaceEthnicityReport.pdf

Bacharach, V. R., Baumeister, A. A., \& Furr, R. M. (2003). Racial and gender science achievement gaps in secondary education. Lournal of Genetic Psychology, 164(1), 115-126.

Bailey, M. J., \& Dynarski, S. M. (2011). Inequality in postsecondary education. In G. Duncan \& R. Murnane (Eds.) Whither opportunity? Rising inequality, schools, and children's life chances (pp. 117-132). New York: Russell Sage.

Bassok, D., Latham, S., \& Rorem, A. (2016). Is kindergarten the new first grade? AERA Open, 2(1). doi:10.1177/2332858415616358

Berkowitz, T., Schaeffer, M. W., Maloney, E. A., Peterson, L., Gregor, C., Levine, S. C., . . . Beilock, S. L. (2015). Math at home adds up to achievement in school. Science, 350(6257), 196-198.

Bianchini, J. A., Dwyer, H. A., Brenner, M. E., \& Wearly, A. J. (2015). Facilitating science and mathematics teachers' talk about equity: What are the strengths and limitations of four strategies for professional learning? Science Education, 99(3), 577-610.

Blank, R. K. (2013). Science instructional time is declining in elementary schools: What are the implications for student achievement and closing the gap? Science Education, 97(6), 830-847.

Bodovski, K., \& Farkas, G. (2007). Do instructional practices contribute to inequality in achievement? The case of mathematics instruction in kindergarten. Lournal of Earlv Childhood Research, 5(3), 301-322.

Bowdon, J., \& Desimone, L. (2014, November 4). More work, less play: Kindergarten, postNCLB. Teachers College Record. Retrieved from http://www.tcrecord.org/Content.asp?ContentId $=17742$

Bronfenbrenner, U. (1992). Ecological systems theory. London: Kingsley.

Bronfenbrenner, U., \& Morris, P. A. (2006). The bioecological model of human development. In W. Damon \& R. M. Lerner (Eds.), Handbook of child psychology (Vol. 1, pp. 793-828). Hoboken, NJ: Wiley. 
Burkhauser, R. V., Feng, S., Jenkins, S. P., \& Larrimore, J. (2012). Recent trends in top income shares in the United States: Reconciling estimates from March CPS and IRS tax return data. Review of Economics and Statistics, 94(2), 371-388.

Carnevale, A. P., Smith, N., \& Strohl, J. (2013). Recovery: Job growth and education requirements through 2020. Washington, DC: Georgetown Public Policy Institute.

Carroll, J. B. (1963). A model of school learning. Teachers College Record, 64(8), 723.

Carroll, J. B. (1989). The Carroll model a 25-year retrospective and prospective view. Educational Researcher, 18(1), 26-31.

Chen, X., \& Weko, T. (2009). Students who study science, technology, engineering, and mathematics (STEM) in postsecondary education (NCES 2009-161). Washington, DC: U.S. Department of Education.

Chetty, R., Friedman, J. N., \& Rockoff, J. E. (2014). Measuring the impacts of teachers: II. Teacher value-added and student outcomes in adulthood. American Economic Review, 104(9), 26332679 .

Chetty, R., Hendren, N., \& Katz, L. F. (2016). The effects of exposure to better neighborhoods on children: New evidence from the Moving to Opportunity experiment. American Economic Review, 106(4), 855-902.

Claessens, A., Engel, M., \& Curran, F. C. (2014). Academic content, student learning, and the persistence of preschool effects. American Educational Research Journal, 51(2), 403-434.

Coleman, J. S., Campbell, C. J., Hobson, J., McPatland, J., Mood, A. M, Weinfeld, F. D., ... York, R. (1966). Equality of educational opportunity. Washington, DC: U.S. Department of Health, Education, and Welfare.

Connor, C. M., Rice, D. C., Canto, A. I., Southerland, S. A., Underwood, P., Kaya, S., ... Morrison, F. J. (2012). Child characteristics by science instruction interactions in second and third grade and their relation to students' content-area knowledge, vocabulary, and reading skill gains. Elementary School Journal, 113(1), 52-75.

Curran, F. C., \& Kellogg, A. T. (2016). Understanding science achievement gaps by race/ethnicity and gender in kindergarten and first grade. Educational Researcher, 45(5), 273-282.

DeNavas-Walt, C., \& Proctor, B. D. (2015). Income and poverty in the United States: 2014: Current population reports. Washington, DC: U.S. Census Bureau.

Duncan, G. J., \& Magnuson, K. (2011). The nature and impact of early achievement skills, attention skills, and behavior problems. In G. Duncan \& R. Murnane (Eds.) Whither opportunity? Rising inequality, schools, and children's life chances (pp. 47-70). New York: Russell Sage.

Duncan, G. J., \& Murnane, R. J. (Eds.). (2011). Whither opportunity? Rising inequality, schools, and children's life chances. New York: Russell Sage.

Fitzpatrick, M. D. (2008). Starting school at four: The effect of universal pre-kindergarten on children's academic achievement. BE Journal of Economic Analysis and Policy, 8(1), 1-40.

Fryer, R. G., \& Levitt, S. D. (2004). Understanding the Black-White test score gap in the first two years of school. Review of Economics and Statistics, 86(2), 447-464.

Gamoran, A., Porter, A. C., Smithson, J., \& White, P. A. (1997). Upgrading high school mathematics instruction: Improving learning opportunities for low-achieving, low-income youth. Educational Evaluation and Policy Analysis, 19(4), 325-338.

Gonzales, P., Williams, T., Jocelyn, L., Roey, S., Kastberg, D., \& Brenwald, S. (2008). Highlights from TIMSS 2007. Washington, DC: U.S. Department of Education, Institute of Education Sciences, National Center for Education Statistics.

Gormley, W. T., Phillips, D., \& Gayer, T. (2008). Preschool programs can boost school readiness. Science, 320(5884), 1723-1724.

Hart, B., \& Risley, T. R. (1995). Meaningful differences in the everyday experience of young American children. Baltimore: Brookes.

Hayes, K. N., \& Trexler, C. J. (2016). Testing predictors of instructional practice in elementary science education: The significant role of accountability. Science Education, 100(2), 266-289.

Jencks, C., \& Phillips, M. (Eds.). (2011). The Black-White test score gap. Washington, DC: Brookings Institution.

Jez, S. J., \& Wassmer, R. W. (2015). The impact of learning time on academic achievement. $\underline{E}$ ucation and Urban Society, 47(3), 284-306. 
Jordan, N. C., Kaplan, D., Nabors Oláh, L., \& Locuniak, M. N. (2006). Number sense growth in kindergarten: A longitudinal investigation of children at risk for mathematics difficulties. Child Development, 77(1), 153-175.

Kaushal, N., Magnuson, K., \& Waldfogel, J. (2011). How is family income related to investments in children's learning? In G. J. Duncan \& R. J. Murnane (Eds.), Whither opportunity? Rising inequality, schools, and children's life chances (pp. 187-206). New York: Russell Sage.

Kohlhaas, K., Lin, H. H., \& Chu, K. L. (2010a). Disaggregated outcomes of gender, ethnicity, and poverty on fifth grade science performance. RMLE Online, 33(7), 1-12.

Kohlhaas, K., Lin, H. H., \& Chu, K. L. (2010b). Science equity in third grade. Elementary School Journal, 110(3), 393-408.

Langdon, D., McKittrick, G., Beede, D., Khan, B., \& Doms, M. (2011). STEM: Good jobs now and for the future (ESA Issue Brief 03-11). Washington, DC: U.S. Department of Commerce.

Lee, O., \& Buxton, C. (2008). Science curriculum and student diversity: A framework for equitable learning opportunities. Elementarv School Journal, 109(2), 123-137.

Lee, O., \& Buxton, C. A. (2010). Multicultural Education Series: Diversity and equity in science education: Research, policy, and practice. New York: Teachers College Press.

Magnuson, K., \& Waldfogel, J. (Eds.). (2008). Steady gains and stalled progress: Inequality and the Black-White test score gap. New York: Russell Sage.

Magnuson, K. A., Ruhm, C., \& Waldfogel, J. (2007). Does prekindergarten improve school preparation and performance? Economics of Education Review, 26(1), 33-51.

Marx, R. W., \& Harris, C. J. (2006). No Child Left Behind and science education: Opportunities, challenges, and risks. Elementary School Journal, 106(5), 467-478.

Meyers, M. K., Rosenbaum, D., Ruhm, C., \& Waldfogel, J. (2004). Inequality in early childhood education and care: What do we know? In Kathryn Neckerman (Ed.), Social inequality (pp. 223270). New York: Russell Sage.

Moore, K. A., Lippman, L. H., \& Ryberg, R. (2015). Improving outcome measures other than achievement. AERA Open, 1(2). doi:10.1177/2332858415579676

Morgan, P. L., Farkas, G., Hillemeier, M. M., \& Maczuga, S. (2016). Science achievement gaps begin very early, persist, and are largely explained by modifiable factors. Educational Researcher, 45(1), 18-35.

Muller, P. A., Stage, F. K., \& Kinzie, J. (2001). Science achievement growth trajectories: Understanding factors related to gender and racial-ethnic differences in precollege science achievement. American Educational Research Journal, 38(4), 981-1012.

National Center for Education Statistics. (2011). The nation's report card: Science 2009. Washington, DC: Institute of Education Sciences, U.S. Department of Education.

National Center for Education Statistics. (2012a). The nation's report card: Science 2011. Washington, DC: Institute of Education Sciences, U.S. Department of Education

National Center for Education Statistics. (2012b). The nation's report card: Science in action: Hands-on and interactive computer tasks from the 2009 science assessment. Washington DC: Institute of Education Sciences, U.S. Department of Education.

NGSS Lead States. (2013). Next generation science standards: For states, by states. Washington, DC: National Academies.

Nussbaum, E. M., Hamilton, L. S., \& Snow, R. E. (1997). Enhancing the validity and usefulness of large-scale educational assessments: IV NELS: 88 science achievement to 12th grade. American Educational Research Journal, 34(1), 151-173.

Oakes, J. (1990). Opportunities, achievement, and choice: Women and minority students in science and mathematics. Review of Research in Education, 16, 153-222.

Paris, S. G., Yambor, K. M., \& Packard, B. W. L. (1998). Hands-on biology: A museum-schooluniversity partnership for enhancing students' interest and learning in science. Elementary School Journal, 98(3), 267-288.

Phillips, D. A., Gormley, W. T., \& Lowenstein, A. E. (2009). Inside the pre-kindergarten door: Classroom climate and instructional time allocation in Tulsa's pre-K programs. Early Childhood Research Quarterly, 24(3), 213-228.

Piketty, T., \& Saez, E. (2003). Income inequality in the United States, 1913-1998. Quarterly Journal of Economics, 118(1), 1-39. 
Quinn, D. M. (2015). Kindergarten Black-White test score gaps re-examining the roles of socioeconomic status and school quality with new data. Sociology of Education, 88(2), 120-139.

Quinn, D. M., \& Cooc, N. (2015). Science achievement gaps by gender and race/ethnicity in elementary and middle school: Trends and predictors. Educational Researcher, 44(6), 336-346.

Quinn, H., Schweingruber, H., \& Keller, T. (Eds.). (2012). A framework for K-12 science education: Practices, crosscutting concepts, and core ideas. Washington, DC: National Academies.

Reardon, S. F. (2011). The widening academic achievement gap between the rich and the poor: New evidence and possible explanations. In G. Duncan \& R. Murnane (Eds.) Whither opportunity? Rising inequality, schools, and children's life chances (pp. 91-116). New York: Russell Sage.

Robinson, K. (2013). Early disparities in mathematics gains among poor and non-poor children. Elementary School Journal, 114(1), 22-47.

Rothstein, R. (2004). Class and schools: Using social, economic, and educational reform to close the achievement gap. Washington, DC: Economic Policy Institute.

Sackes, M., Trundle, K. C., \& Bell, R. L. (2013). Science learning experiences in kindergarten and children's growth in science performance in elementary grades. Education and Science, 38(167), 114-127.

Sackes, M., Trundle, K., Bell, R., \& O’Connell, A. (2011). The influence of early science experience in kindergarten on children's immediate and later science achievement: Evidence from the Early Childhood Longitudinal Study. Lournal of Research in Science Teaching, 48(2), 217-235.

Suter, L. E. (2014). Visiting science museums during middle and high school: A longitudinal analysis of student performance in science. Science Education, 98(5), 815-839.

Top 10 legislative issues to watch in 2015. (2015). Governing. Retrieved from http://www.governing .com/topics/politics/gov-issues-to-watch-2015.html

Tourangeau, K., Nord, C., Lê, T., Sorongon, A. G., Hagedorn, M. C., Daly, P., . . Mulligan, G. M. (2015). Early Childhood Longitudinal Study, Kindergarten Class of 2010-11 (ECLS-K:2011), user's manual for the ECLS-K:2011 kindergarten data file and electronic codebook (Public version). Washington, DC: U.S. Department of Education, National Center for Education Statistics.

Tourangeau, K., Nord, C., Lê, T., Sorongon, A. G., \& Najarian, M. (2009). Early Childhood Longitudinal Study, Kindergarten Class of 1998-99 (ECLS-K): Combined user's manual for the ECLS-K eighth-grade and K-8 full sample data files and electronic codebooks (NCES 2009-004). Washington, DC: U.S. Department of Education, National Center for Education Statistics.

$\mathrm{Tu}, \mathrm{T}$. (2006). Preschool science environment: What is available in a preschool classroom? Early Childhood Education Journal, 33(4), 245-251.

U.S. Department of Education. (2012). Table 168. Average National Assessment of Educational Progress (NAEP) science scale score, standard deviation, and percentage of students attaining science achievement levels, by grade level, selected student and school characteristics, and percentile: 2009 and 2011. Retrieved from https://nces.ed.gov/programs/digest/d12/tables/dt12 _168.asp

Wang, J. (1998). Opportunity to learn: The impacts and policy implications. Educational Evaluation and Policy Analysis, 20(3), 137-156.

Wilder, T., Jacobsen, R., \& Rothstein, R. (2008). A report card on comprehensive equity: Racial gaps in the nation's youth outcomes. Retrieved from http://www.epi.org/publications/entry /racial_gaps 